Marzena BuChNAT

AleKSANDRA JaSIELSKA

Uniwersytet im. Adama Mickiewicza

$w$ Poznaniu

\title{
WIEDZA NA TEMAT SMUTKU U DZIECI Z RÓŻNYM POZIOMEM ROZWOJU INTELEKTUALNEGO ${ }^{1}$
}

\begin{abstract}
AвSTRACт. Buchnat Marzena, Jasielska Aleksandra, Wiedza na temat smutku u dzieci z różnym poziomem rozwoju intelektualnego [Knowledge about the Sadness in Children with Different Levels of Intellectual Development]. Studia Edukacyjne nr 47, 2018, Poznań 2018, pp. 257-287. Adam Mickiewicz University Press. ISSN 1233-6688. DOI: 10.14746/se.2018.47.17

The aim of this study was to characterize the knowledge about the joy in children with mild intellectual disability. The premises relating to the mental functioning of these children suggest that this knowledge is poorer and less complex than the knowledge of their peers in the intellectual norm. The study used the authoring tool to measure children's knowledge of emotions, including joy. The tool takes into account the cognitive representation of the basic emotions available in three codes: image, verbal, semantic and interconnection between the codes - perception, symbolization and conceptualization, which perform the functions of perception, expression and understanding. The study included children with the intellectual norm $(\mathrm{N}=30)$ and children with mild intellectual disability $(\mathrm{N}=30)$. The results mainly indicate the differences in how happiness is understood by particular groups, to the detriment of children with disability. The character of the results is largely determined by the level of organization of knowledge about joy and accompanying mental operations.
\end{abstract}

Key words: knowledge about emotions, mild intellectual disability, joy

\section{Wstęp}

Uczennica trzeciej klasy szkoły podstawowej stwierdziła, że „smutek jest podobny do deszczu, ulewy i wiatru, jak deszcz pada to wtedy wszystko jest

${ }^{1}$ Badanie częściowo zrealizowane dzięki programowi „Staże i szkolenia praktyczne pracowników naukowych placówek naukowych i pracowników naukowych, naukowo-dydaktycznych i dydaktycznych uczelni w przedsiębiorstwach", przyznanego autorkom przez Urząd Marszałkowski Województwa Wielkopolskiego i Unii Europejskiej (działania 8.2 i poddziałanie 8.2.1). 
szare" ${ }^{2}$, z kolei jej kolega powiedział, że „,smutek przypomina ciemność”3. Wypowiedzi takie były możliwe, ponieważ każda emocja, podobnie jak inne zjawiska rzeczywistości pozajęzykowej, może zostać przedmiotem reprezentacji umysłowej i zostać zapisana w odmiennym niż macierzysty systemie znaków, pod postacią koncepcji emocji, której wyrazem w przytoczonych przykładach była metafora językowa ${ }^{4}$. Dzięki tej prawidłowości wrodzona, biologicznie uwarunkowana dyspozycja organizmu („pierwotny” fizjologiczno-somatyczny afekt) staje się przedmiotem myśli („,wtórne” struktury interpretacyjne) ${ }^{5}$. Przyjmuje się tym samym założenie, że o życiu uczuciowym jednostki decyduje zarówno przeżywanie emocji, jak i sposób reprezentowania tego doświadczania w systemie poznawczym (tzw. „emocje bez emocji” ${ }^{6}$ ). W przestrzeni mentalnej, w której dominują abstrakcyjne formy zapisu, konstytuujące wiedzę jednostki na temat emocji ${ }^{7}$. Rodzi się zatem pytanie, czy jednostki, dla których charakterystyczne są deficyty w zakresie procesów intelektualnych mają szanse na posiadanie równie zaawansowanej wiedzy na temat smutku, a w konsekwencji regulowanie tej emocji, jak osoby w normie intelektualnej. Odpowiedź na to pytanie będzie poszukiwana w kontekście wiedzy o smutku, jaką posiadają dzieci z lekką niepełnosprawnością intelektualną.

\section{Wiedza na temat emocji}

\section{Wiedza o emocjach stanowi}

zasób informacji dotyczących emocji i ich doświadczenia przez siebie samego, jak i przez innych ludzi, który może zostać wykorzystany, by rozumieć i interpretować wydarzenia rozgrywające się $\mathrm{w}$ otoczeniu jednostki ${ }^{8}$.

${ }^{2}$ M. Wiśniewska-Kin, „Miłość jest jak wiatrak“ - czyli o poznawczej naturze metafor dziecięcych, Łódź 2009, s. 162.

3 Tamże, s. 164.

${ }^{4}$ I. Nowakowska-Kempna, Konceptualizacja uczuć w języku polskim, Część II. Data, Warszawa 2000, s. 87-88; G.M. White, Representing Emotional Meaning: Category, Metaphor, Schema, Discourse, [w:] Handbook of Emotions, red. M. Lewis, J.M. Haviland-Jones, New York 2000, s. 30-44.

${ }^{5}$ B. Parkinson, Ideas and realities of emotion, London 1995; P.M. Niedenthal, Emotion Concepts, [w:] Handbook of Emotions, s. 587-600; G.M. White, Representing Emotional Meaning, s. 30-44.

${ }^{6}$ A. Duszak, O emocjach bez emocji. Gniew w perspektywie lingwistycznej, [w:] Anatomia gniewu. Emocje negatywne w językach $i$ kulturach świata, red. A. Duszak N. Pawlak, Warszawa: 2003, s. 13-23; A. Jasielska, Charakterystyka i konsekwencje potocznego rozumienia emocji, Poznań 2013; T. Maruszewski, E. Ścigała, Emocje - aleksytymia - poznanie, Poznań 1998; D. Szumska, O emocjach bez emocji, Język a Kultura, 2000, 14, s. 199-208.

7 A. Jasielska, Charakterystyka i konsekwencje; T. Maruszewski, E. Ścigała, Emocje - aleksytymia - poznanie; M. Stępień-Nycz, Rozwój reprezentacji emocji w dzieciństwie, Warszawa 2015.

${ }^{8}$ E.M. Brenner, P. Salovey, Regulacja emocjonalna w okresie dzieciństwa: aspekty rozwojowe, interpersonalne i indywidualne, [w:] Rozwój emocjonalny a inteligencja emocjonalna, red. P. Salovey, D.J. Sluyter, Poznań 1999, s. 302, 315. 
To dzięki emocjonalnej wiedzy jednostka wie, czym jest emocja i jak działa, identyfikuje i rozumie przeżycia emocjonalne swoje oraz innych ludzi ${ }^{9}$, a ponadto to jak jednostka rozumie emocje pozostaje w związku z jej funkcjonowaniem emocjonalnym ${ }^{10}$. Elementami tej wiedzy są między innymi informacje na temat: pochodzenia emocji, układu czynników sprawczych odpowiedzialnych za pojawienie się danej emocji, wpływu emocji na zachowanie specyficznych dla danej emocji technik kontroli i aktywacji, związku danej emocji z innymi, wartości przypisywanej danej emocji w indywidualnym systemie znaczeń, przewidywania ich przebiegu, czynników, od których zależy ich siła, czas trwania, następstwa i tym podobne ${ }^{11}$. Dzięki wiedzy o emocjach

(...) wiemy co to znaczy być złym, jak się zachować, kiedy jesteśmy przestraszeni, co mówimy kiedy jesteśmy zakochani i jakie wydarzenia prowadzą nas do frustracji czy radości. Wiedza o emocjach jest używana, kiedy rozmawiamy z ludźmi, piszemy maile czy czytamy książkę i pozwala nam nadawać sens naszym własnym emocjom i emocjom innych ${ }^{12}$.

Takie ujęcie jest konsekwencją założenia psychologii potocznej ${ }^{13}$, mówiącego o tym, że psychologia ta zawiera tak zwaną wiedzę operacyjną, której jednym $\mathrm{z}$ aspektów jest wiedza deskryptywna o charakterze przede wszystkim informacyjnym, drugim zaś wiedza interpretacyjna wykorzystywana podczas zachowywania się w określony sposób, na przykład w sytuacjach emotogennych.

Jedną $\mathrm{z}$ dyskutowanych $\mathrm{w}$ literaturze przedmiotu form wiedzy emocjonalnej, obok na przykład ujęcia narracyjnego czy rdzennego ${ }^{14}$, jest model kodów umysłowych i wzajemnych powiązań pomiędzy nimi (por. koncepcja kod-emocje Obuchowskiego $\left.{ }^{15}\right)$. Taki charakter ma koncepcja Bucci ${ }^{16}$, która

${ }^{9}$ B. Górecka-Mostowicz, Co dzieci wiedza o emocjach, Kraków 2005; I. Nowakowska-Kempna, Konceptualizacja uczuć w języku polskim; B. Parkinson, Ideas and realities; K. Smith, Social psychological perspectives on laypersons' theories of emotion, [w:] Everyday Conceptions of Emotion: An Introduction to the Psychology, Anthropology, and Linguistic of Emotion, red. J.A. Russell, J.-M. Fernandez-Dols, A.S.R. Manstead, J.C. Wellenkamp, Dordtrecht 1995, s. 411.

${ }_{10}$ A. Jasielska, Charakterystyka $i$ konsekwencje.

11 J.M. Fernandez-Dols, J.A. Bachorowski, Emotions. Encyclopedia of psychological Assessment, 2009, http://www.sageereference.com/psychaassessment/Article_n76.html., [dostęp: 12.01.2018]; T. Maruszewski, E. Ścigała, Emocje - aleksytymia - poznanie, s. 73; J.A. Russell, G. Lemay, Emotion Concepts, [w:] Handbook of Emotions, red. M. Lewis, J.M. Haviland-Jones, New York 2000, s. 493.

${ }_{12}$ Tłum. autorek za: S. Oosterwijk i in., Embodied emotion concepts: How generating words about pride and disappointment influences posture, European Journal of Social Psychology, 2009, 39, s. 425.

${ }^{13}$ F. Heider, The psychology of interpersonal relationships, New York 1958

14 A. Jasielska, Charakterystyka i konsekwencje, s. 37-61.

${ }^{15}$ K. Obuchowski, Kody umystu i emocje, Łódź 2004.

${ }^{16}$ W. Bucci, The Need for a "Psychoanalytic Psychology" in the Cognitive Science Field, Psychoanalytic Psychology, 2000, 17, s. 203-224. 
zakłada, że schematy kodowania emocji są schematami pamięciowymi, jakie reprezentują interakcje z osobami znaczącymi z wczesnego okresu życia. Reprezentacja emocji powstaje w wyniku niuansowego, precyzyjnego i wielokrotnego przekodowywania między specyficznymi kodami. Wyróżniane kody to: 1) subsymboliczny operujący na danych zmysłowych, cielesnych i motorycznych; 2) wyobrażeń symbolicznych przybierających postać symboli i obrazów; 3) symboli słownych zawierających werbalne schematy emocji. W zakresie wymienionych kodów istnieją dwa podstawowe tryby przetwarzania emocjonalno-pamięciowego. Pierwszy, pojawiający się na wcześniejszych etapach rozwoju, ukryty, przedwerbalny i asocjacyjny, obejmujący poziom subsymboliczny i poziom wyobrażeń symbolicznych. System jest powiązany z reakcjami cielesnymi. W jego obrębie są obecne automatyczne i szybkie procesy, takie jak torowanie czy rozprzestrzeniająca się aktywacja. Drugi tryb pojawia się na późniejszych etapach rozwoju, przybierając postać propozycjonalnego systemu racjonalnego, który jest analityczny, refleksyjny i logiczny. System ten opiera się na zaawansowanych funkcjach wykonawczych i dostępnej werbalnie informacji semantycznej. Obydwa systemy połączone są wzajemnie za pomocą "łączy referencyjnych". Kiedy zachodzi integracja reprezentacji somatycznych, sensorycznych i motorycznych z reprezentacjami symbolicznymi $\mathrm{w}$ ramach schematów emocjonalnych, wówczas odzwierciedlenie emocji w strukturach umysłu jest prawidłowe ${ }^{17}$.

Zbliżony charakter ma propozycja Karmiloff-Smith ${ }^{18}$, która wprowadza zbliżone do "łączy referencyjnych" pojęcie "redeskrypcji reprezentacji”, rozumianej jako ciągły proces „przepisywania” wiedzy w różnych kodach na różnym poziomie jawności. Zdaniem Autorki, istnieją cztery poziomy jawności wyznaczone zróżnicowanym dostępem świadomości i możliwością werbalizacji oraz operacjami poznawczymi, które na tych danych mogą być wykonywane. Proces redeskrypcji umożliwia wykorzystanie przez jednostkę wiedzy jawnej i utajonej. Może być inicjowany z zewnątrz i od wewnątrz. Zawiera trzy rekurencyjne fazy zachodzące wielokrotnie w ciągu rozwoju. $\mathrm{W}$ pierwszej $\mathrm{z}$ nich zachodzi dodawanie nowych informacji i proceduralizacja prowadząca aż do tak zwanego behawioralnego mistrzostwa. Na tym etapie zachowanie jest w całości niedostępne świadomemu poznaniu. Faza ta jest kierowana przez dane i zmierza do automatyzacji zachowania. Przypuszczalnie w obrębie emocji chodziłoby o nabywanie takich umiejętności emocjonalnych, jak na przykład rozpoznawanie emocji czy ich wyrażanie. W fazie drugiej następuje zwrot do zewnętrznych danych ku wewnętrznej

${ }_{17} \mathrm{~W}$. Bucci, The interplay of subsymbolic and symbolic processes in psychoanalytic treatment, Psychoanalytic Dialogues, 2005, 15, s. 855-873.

${ }_{18}$ A. Karmiloff-Smith, Beyond modularity: A developmental perspective on cognitive science, Cambridge 1995. 
reprezentacji. Jednostka podejmuje refleksję nad posiadaną wiedzą, dzięki czemu ma szansę na zaobserwowanie jakichś zasad, obecnych w zachowaniu emocjonalnym. W fazie trzeciej następuje połączenie zewnętrznych danych i wewnętrznej reprezentacji pod postacią utworzenia nowego odwzorowania pomiędzy dwoma źródłami danych. Karmiloff-Smith ${ }^{19}$ jest zdania, że proces redeskrypcji i będący jego następstwem rozwój reprezentacji może postępować w dwóch kierunkach. Z jednej strony chodzi o proces deklarywizacji (por. deproceduralizacja) wiedzy zawartej w procedurach, dzięki któremu jednostka nie tylko potrafi wyrazić emocji, ale także deklaratywnie jest w stanie zreferować jak to zrobić, na przykład wie, jakich użyć słów, aby wyrazić doświadczane emocje, opisać i zna reguły rządzące ujawnianiem emocji. Drugi kierunek to proceduralizacja wiedzy deklaratywnej pod dyktando instrukcji słownej zgodnie z zasadami nabywania wiedzy proceduralnej, która w dalszej kolejności ulegnie automatyzacji i pozwoli jednostce na przykład regulować emocje w sytuacji ekspozycji społecznej ${ }^{20}$.

Powyższe propozycje uzupełnia oparta na triangulacji Odgena i Richardsa $^{21}$ koncepcja psychicznej reprezentacji emocji, autorstwa Maruszewskiego i Ścigały ${ }^{22}$. Autorzy ci przyjmują, że wiedza o emocjach jest hierarchicznie zorganizowana na podstawie kodów obrazowych, werbalnych i abstrakcyjnych oraz na procesach związanych $\mathrm{z}$ ich przekształceniami ${ }^{23}$. W ramach kodu obrazowego powstają prymitywne, niedostępne świadomości reprezentacje skryptowe wypełnione zindywidualizowaną treścią i jako takie stanowią podstawę do odmiennego reagowania różnych osób na te same bodźce sytuacyjne. Kod ten łączy się z kodem werbalnym procesami werbalizacji i wizualizacji. W kodzie werbalnym reprezentacja emocji ma budowę prototypową i zawiera typową, uogólnioną wiedzę dotyczącą emocji najczęściej doświadczanych w określonych sytuacjach. Jego połączenie z kodem abstrakcyjnym stanowią procesy semantyzacji i desemantyzacji. W kodzie abstrakcyjnym powstaje najbardziej uogólniona reprezentacja emocji polegająca na nadawaniu znaczenia. $W$ jej ramach emocje reprezentowane są jako pojęcia, które zawierają aprioryczną wiedzę w postaci potocznych teorii emocji. Kod abstrakcyjny łączy się z obrazowym parą procesów, takich jak symbolizacja i desymbolizacja. Poszczególne kody i ich wzajemne przekształcania nie zawierają tylko aspektu treściowego wiedzy emocjonalnej, ale także wzbudzane $\mathrm{w}$ ich ramach czynności poznawcze i instrumentalne pod postacią takich

\footnotetext{
19 Tamże.

${ }^{20}$ M. Stępień-Nycz, Rozwój reprezentacji emocji, s. 41-42.

${ }^{21}$ C.K. Odgen, L.A. Richards, The meaning of meaning, Orlando 1989.

${ }^{22}$ T. Maruszewski, E. Ścigała, Poznawcza reprezentacja emocji, Przegląd Psychologiczny,
} 1995 , 38, s. 245-278.

${ }^{23}$ T. Maruszewski, E. Ścigała, Emocje - aleksytymia - poznanie. 
funkcji, jak spostrzeganie (percepcja), wyrażanie (ekspresja) i rozumienie (konceptualizacja) emocji.

Modele teoretyczne dotyczące wiedzy społecznej, w tym między innymi wiedzy na temat emocji wskazują na istnienie w jej obrębie dwóch składników: percepcyjnego (korespondującego z procesami spostrzegania i rozumienia) i konceptualnego (korespondującego $\mathrm{z}$ tzw. teoriami umysłu) ${ }^{24}$. Istnieje zgoda, że dopiero wiedza na temat emocji kodująca dane w sposób abstrakcyjny i wykorzystująca do tego złożone procesy myślowe daje jednostce środki kontroli nad emocjami.

\section{Sfera emocjonalna dzieci z niepełnosprawnością intelektualną}

Niepełnosprawność intelektualna może stanowić jeden z czynników determinujących poziom zdolności rozpoznawania emocji ${ }^{25}$. Wywiera ona wpływ na emocjonalną wiedzę jednostki, ponieważ wiedza ta jest zorganizowana na podstawie kodu obrazowego, werbalnego, abstrakcyjnego i wymaga zaangażowania czynności poznawczych oraz instrumentalnych, takich jak spostrzeganie (percepcja), wyrażanie (ekspresja) i rozumienie (konceptualizacja), które u tych osób są zaburzone.

Według Międzynarodowej Klasyfikacji Chorób (ICD-10), upośledzenie umysłowe to

stan zahamowania lub niepełnego rozwoju umysłu, które charakteryzuje się zwłaszcza uszkodzeniem umiejętności ujawniających się w okresie rozwoju i składających się na ogólny poziom inteligencji - to jest: zdolności poznawczych, mowy, ruchowych i społecznych ${ }^{26}$.

Zaburzenie zostało umieszczone w grupie zaburzeń umysłowych i zachowania (kod F 70-F79). Twórcy ICD-10 wyróżnili na podstawie przedziałów ilorazów inteligencji poziomy niepełnosprawności intelektualnej. Osoba z niepełnosprawnością intelektualną w stopniu lekkim (IQ 50-69) w dorosłości osiąga maksymalny poziom rozwoju umysłowego porównywalny do wie$\mathrm{ku}$ inteligencji 9-12 lat w normie (kod F 70)27.

${ }^{24}$ M. Stępień-Nycz, Rozwój reprezentacji emocji, s. 35.

${ }^{25}$ K.R. Cebula, D.G. Moore, J.G. Wishart, Social cognition in children with Down's syndrome: Challenges to research and theory building, Journal of Intellectual Disability Research, 2006, 54, s. 113-134; J.G. Wishart i in., Understanding of facial expressions of emotion by children with intellectual disabilities of differing aetiology, Journal of Intellectual Disability Research, 2007, 51(7), s. 551-563.

${ }^{26}$ S. Pużyński, J. Wciórka, Klasyfikacja Zaburzeń Psychicznych i Zaburzeń Zachowania ICD-10, Kraków 2000, s. 189.

27 Tamże, s. 190. 
Budowanie wiedzy o emocjach oparte jest na procesach percepcji i konceptualizacji. W zakresie rozumienia wiedzy dzieci z lekką niepełnosprawnością intelektualną, z uwagi na swoją specyfikę rozwojową, wykazują ograniczenia, pomimo że rozwój poznawczy dziecka z lekką niepełnosprawnością intelektualną obejmuje te same fazy co rozwój dzieci w normie intelektualnej, ale przebiega wolniej i nie przekracza fazy myślenia konkretnoobrazowego ${ }^{28}$. Nie dochodzi zatem do osiągnięcia poziomu operacji formalnych, przez co myślenie tych dzieci nie jest abstrakcyjne i hipotetyczno-dedukcyjne ${ }^{29}$. Skutkuje to deficytami w zakresie analizy, syntezy, uogólniania, czy abstrahowania, co warunkuje sposób rozumienia emocji. Dzieci z lekką niepełnosprawnością intelektualną mają upośledzoną zdolność wnioskowania sylogistycznego, indukcyjnego oraz przez analogię. Ich wnioskowanie charakteryzuje się zmniejszonym krytycyzmem, trudnościami w uchwyceniu istoty zachodzących zależności czy zdarzeń, związków między wnioskiem a przesłankami. Ponadto, dzieci te w okresie wczesnoszkolnym nie osiągają stanu stabilnej równowagi, która umożliwia swobodne przenoszenie się między poziomami myślenia, co często powoduje gubienie wątków, sztywność myślenia, małą elastyczność. Trudności ze zmianą sposobu myślenia prowadzą do stosowania znanych schematów w rozwiązywaniu nowych zadan ${ }^{30}$. Sztywność myślenia, popełnianie błędów dotyczących logiki, nieumiejętność dokonywania uogólnień czy abstrahowań powoduje niski poziom zrozumienia emocji, szczególnie w zmieniających się warunkach poznania. Zaburzenia w zakresie myślenia abstrakcyjnego i procesie decentracji powodują, że uczucia są odbierane jako element danej sytuacji, co w znaczący sposób obniża umiejętność wczuwania się w sytuację drugiego człowieka. Dopiero długotrwały trening empatii pozwala im na zrozumienie subiektywności uczuć i ich kontekstu sytuacyjnego $^{31}$. Niski poziom empatii wpływa też na budowanie więzi emocjonalnych i umiejętność komunikowania się (odbieranie i nadawanie komunikatów $\mathrm{z}$ rozpoznaniem intencji partnera interakcji).

Z uwagi na to, że poziom myślenia dzieci z lekką niepełnosprawnością intelektualną implikuje inne procesy poznawcze, percepcja wiedzy o emocjach

${ }^{28}$ J. Piaget, B. Inhelder, Psychologia dziecka, Wrocław 1993, s. 65.

${ }_{29}$ M. Kościelska, Oblicza upośledzenia, Warszawa 1998, s. 100; I. Obuchowska, Dzieci upośledzone w stopniu lekkim, [w:] Dziecko niepetnosprawne w rodzinie, red. I. Obuchowska, Warszawa 1999, s. 233-234; W. Pilecka, Psychoruchowy rozwój dzieci o obniżonej sprawności umystowej, [w:] Stymulacja psychoruchowego rozwoju dzieci o obniżonej sprawności umysłowej, red. W. Pilecka, J. Pilecki, Kraków 2003, s. 17; J. Wyczesany, Z. Gajdzica, Uwarunkowania edukacji i rehabilitacji uczniów o specjalnych potrzebach rozwoju, Kraków 2006, s. 69.

${ }^{30} \mathrm{M}$. Buchnat, Formy organizacji ksztatcenia dziecka z lekka niepetnosprawnościa intelektualna, Poznań 2015, s. 37.

31 Z. Gajdzica, Edukacyjne konteksty bezradności społecznej osób z lekkim upośledzeniem umystowym, Katowice 2007; R.J. Simeonsson, D.R. Bailey, Assessing Needs of Family with Handicapped Infants, Journal of Special Education, 1988, 22, s. 117-127. 
też jest uboższa, ponieważ nakładają się na ten stan deficyty w obszarze poszczególnych procesów poznawczych. Procesy spostrzegania u dzieci z lekką niepełnosprawnością intelektualną cechują się niedokładnością, wąskim zakresem oraz zwolnionym tempem ${ }^{32}$. Wpływ na niedokładność, mniejszy zakres i spowolnione tempo spostrzegania mają zaburzenia percepcji słuchowej i wzrokowej, przez co dzieci z lekką niepełnosprawnością intelektualną cechuje zniekształcone postrzeganie rzeczywistości. Zauważają one głównie zewnętrzne cechy charakterystyczne obiektów, na przykład kolor, pomijając cechy szczegółowe. Mają problem z umiejscowieniem ich w przestrzeni i z ukształtowaniem ich pojęcia. Taki poziom spostrzegania powoduje trudności w zakresie porównywania przedmiotów, wyszukiwania ich podobieństw i różnic, a także wyszukiwania wzajemnych powiązań. Dzieci z lekką niepełnosprawnością intelektualną postrzegają znacznie mniej przedmiotów w określonym czasie niż dzieci z normą intelektualną, za co odpowiedzialny jest wolniejszy przebieg procesów korowych, a odbiór otaczającej rzeczywistości jest jeszcze uboższy ${ }^{33}$. Takie trudności mają przełożenie na zakres postrzegania społecznego, utrudniają obserwację zmieniających się uczuć, nastrojów, śledzenia zmian w zachowaniu drugiej osoby, jak i u samego siebie, co zuboża możliwość postrzegania jak i zrozumienia emocji. Sytuację tę pogłębiają deficyty w zakresie koncentracji uwagi, które jeszcze bardziej utrudniają zbieranie danych potrzebnych do określania stanu emocjonalnego. Mała podzielność uwagi sprawia, że dzieci te $\mathrm{w}$ procesie zbierania informacji nie potrafią efektywnie korzystać z różnych źródeł. Oprócz czynników poznawczych, doświadczenie interakcji społecznych oraz orientacja w zasadach współżycia społecznego determinuje umiejętność utrzymania uwagi społecznej, intersubiektywności, która będzie miała znaczenie dla tworzenia się wiedzy emocjonalnej. Niestety, również i te procesy często bywają opóźnione, różniąc się jakościowo od obserwowanych u dzieci o prawidłowym rozwoju ${ }^{34}$.

Ograniczony odbiór rzeczywistości będzie miał znaczenie dla jej zrozumienia, które również jest ograniczone. Na dodatek, również korzystanie

${ }^{32}$ J. Wyczesany, Z. Gajdzica, Uwarunkowania edukacji i rehabilitacji uczniów, s. 68; K.J. Zabłocki, Upośledzenie umysłowe - wybrane zagadnienia edukacji i terapii, Płock 2003, s. 29.

${ }^{33}$ M. Buchnat, Formy organizacji ksztatcenia dziecka, s. 40; I. Chrzanowska, Funkcjonowanie dzieci upośledzonych umystowo w stopniu lekkim w szkole podstawowej, Łódź 2003, s. 10; J. Wyczesany, Z. Gajdzica, Uwarunkowania edukacji i rehabilitacji uczniów, s. 68; K.J. Zabłocki, Upośledzenie, s. 29.

${ }^{34}$ K.R. Cebula, J. Wishart, Social cognition in children, s. 43-86; K.R. Cebula, D.G. Moore, J.G. Wishart, Social cognition in children with Down's syndrome: Challenges to research and theory building, Journal of Intellectual Disability Research, 2006, 54, s. 113-134; D.J. Fidler, The emergence of a syndromespecific personality profile in young children with Down syndrome, Down Syndrome Research and Practice, 2006, 10(2), s. 53-60. 
$\mathrm{z}$ wiedzy już zdobytej jest utrudnione $\mathrm{z}$ uwagi na niski poziom pamięci. Zdolność stosowania coraz to bardziej zaawansowanych strategii zapamiętywania jest, niestety, powiązana ze zmianami w zakresie myślenia ${ }^{35}$, dlatego pamięć logiczna osób z lekką niepełnosprawnością intelektualną jest bardzo słaba, natomiast pamięć mechaniczna, skojarzeniowa - na przeciętnym poziomie $^{36}$. Osoby te mają problemy we wszystkich obszarach procesów pamięciowych, począwszy od kodowania pobieranych informacji, przez aktywne podtrzymywanie informacji w pętli artykulacyjnej, aż do ogólnego deficytu pamięci krótkotrwałej i długotrwałej ${ }^{37}$. Lepiej zapamiętują materiał dotyczący teraźniejszości, związany z własnymi doświadczeniami, oparty na emocjach, który jest przechowywany w pamięci epizodycznej. Ten rodzaj pamięci u dzieci z lekką niepełnosprawnością intelektualną występuje na poziomie dzieci w normie. Znaczne ograniczenia obserwowane są natomiast w zakresie pamięci semantycznej, ponieważ zapamiętanie komunikatów językowych tworzących system wiedzy wymaga złożonych operacji pojęciowych, które są u nich zaburzone ${ }^{38}$.

Dzieci z lekką niepełnosprawnością intelektualną charakteryzują się ograniczoną pojemnością pamięci, wykazują deficyty w przyswajaniu nowego materiału, szybko go zapominają, a odtwarzanie go z pamięci jest niedokładne. Nie potrafią też wykorzystać nowo zdobytej wiedzy w praktyce i często uczą się na pamięć, bez zrozumienia ${ }^{39}$. Takie specyficzne cechy pamięci utrudniają zrozumienie sytuacji społecznych, odczytywanie emocji, które są w sposobie wyrażania bardzo zmienne i zależą od kontekstu społeczno-kulturowego.

Werbalizacja stanów emocjonalnych również będzie uboższa u dzieci z lekką niepełnosprawnością intelektualną, ponieważ osoby te charakteryzują się zaburzeniami na poziomie kompetencji językowych. Grabias ${ }^{40}$ wskazuje, że deficyt ten wynika ze stopnia niepełnosprawności intelektualnej, stopień nasilenia zaburzeń mowy jest wprost proporcjonalny do głębokości niepełnosprawności.

W zakresie leksykalnym mowa dzieci z lekką niepełnosprawnością intelektualną charakteryzuje się przede wszystkim ubogim słownictwem. W ich wypowiedziach dominują rzeczowniki i czasowniki rzadko posługują się przymiotnikami i przysłówkami. Przymiotniki, których używają, określają

${ }^{35}$ R. Stefańska-Klar, Późne dzieciństwo. Młodszy wiek szkolny, [w:] Psychologia rozwoju człowieka, red. B. Harwas-Napierała, J. Trempała, t. 2, Warszawa 2005, s. 135.

${ }^{36} \mathrm{M}$. Kijewska, O możliwościach usprawniania pamięci dzieci z niepetnosprawnościa intelektualna w stopniu lekkim, [w:] Nauczanie uczniów z niepetnosprawnościa intelektualna w stopniu lekkim, red. S.P. Sadowska, Toruń 2006, s. 283.

${ }^{37}$ E. Nęcka, Inteligencja: geneza - struktura - funkcje, Gdańsk 2003, s. 182-185.

38 R. Kościelak, Psychologiczne podstawy upośledzonych umystowo, Warszawa 1989, s. 48.

39 J. Głodkowska, Poznanie ucznia szkoty specjalnej, Warszawa 1999, s. 68.

40 S.P. Grabias, Jezzyk w zachowaniach społecznych, Lublin 2001, s. 33. 
cechy sensoryczne, a przysłówki odnoszą się do sposobu wykonania czynności ${ }^{41}$. Dzieci z lekką niepełnosprawnością intelektualną najczęściej posługują się zdaniami pojedynczymi. Wykazują również trudności w dekodowaniu znaczeń poszczególnych słów czy zdań, co utrudnia im prawidłowe rozpoznanie przekazu. Na problemy ze zrozumieniem przekazu nakłada się niska umiejętność uchwycenia sensu zastanej sytuacji. Brak zrozumienia kontekstu sytuacyjnego, niska umiejętność wykorzystania posiadanej wiedzy do wyjaśnienia danego stanu rzeczywistości, trudności w dostrzeżeniu problemu i jego nazwaniu obniżają kompetencje komunikacyjne dzieci z lekką niepełnosprawnością intelektualną ${ }^{42}$. Przeprowadzone badania wskazują jednak, że aktywność językowa takich dzieci zależy od stworzonej im sytuacji społecznej, klimatu emocjonalnego $\mathrm{w}$ rodzinie, motywacji do mówienia oraz osobowości dziecka ${ }^{43}$. Wyniki badań Abbeduto i Biblera Nuccio ${ }^{44}$ wskazują, że osoby z niepełnosprawnością intelektualną formułując wypowiedzi, biorą pod uwagę stan emocjonalny partnera rozmowy oraz poziom jego aktywności. Wyniki przedstawionych badań prowadzą do stwierdzenia, że rozwój mowy uwarunkowany jest jakością relacji z otoczeniem społecznym ${ }^{45}$. Osoby z lekką niepełnosprawnością intelektualną mają też problemy z formułowaniem komunikatów zrozumiałych dla odbiorców, jednak winę za brak porozumienia często przypisują odbiorcy. Wykazują one również deficyty w przekazywaniu informacji deskryptywnych, a także kiedy komunikat dotyczy sytuacji wyobrażeniowej, abstrakcyjnej lub nowej, nieznanej dziecku z wcześniejszych doświadczeń ${ }^{46}$. Z badań przeprowadzonych przez Abbeduto i współpracowników ${ }^{47}$ wynika, że osoby z lekką niepełnosprawnością intelektualną mają problemy z unikaniem zakłóceń w porozumiewaniu się, na przykład zadawania pytań wyjaśniających daną sytuację. Dzieci z lekką niepełnosprawnością intelektualną w sytuacji niezrozumienia komunikatu zamiast poprosić partnera rozmowy o wyjaśnienie, próbowały odgadnąć jego intencje, niestety często bez powodzenia, co prowadziło do przerwania rozmowy. Wszystkie

${ }^{41}$ A. Rakowska, Znajomość określonych grup stownictwa przez dzieci lekko upośledzonych umystowo, Szkoła Specjalna, 1980, 2, s. 121-130; J. Wyczesany, Z. Gajdzica, Uwarunkowania edukacji i rehabilitacji uczniów, s. 70.

${ }_{2}$ A. Rakowska, Język mówiony dzieci lekko upośledzonych umystowo w sytuacji szkolnej, [w:] Dyskurs edukacyjny, red. T. Rittel, Kraków 1996, s. 59.

${ }^{43}$ U. Jęczeń, Uwarunkowania rozwoju kompetencji językowej i komunikacyjnej u dzieci upośledzonych umystowo, Logopedia, 2003, 32, s. 129.

${ }^{44}$ L. Abbeduto i in., Identifying the referents of spoken messages: The use of context and clasification requests by children with mental retardation and by non retarded children, American Journal on Mental Retardation, 1991, 93, s. 551-562.

${ }^{45}$ M. Buchnat, Formy organizacji ksztatcenia dziecka, s. 43.

46 A. Twardowski, Ksztattowanie dialogowej kompetencji komunikacyjnej u uczniów niepetnosprawnych intelektualnie, Poznań 2002, s. 13-19.

47 L. Abbeduto i in., Identifying the referents of spoken messages, s. 551-562. 
wymienione trudności charakteryzujące dzieci z lekką niepełnosprawnością intelektualną powodują ograniczenia komunikacyjne wpływające na sposób ich wyrażania się.

Osiągany przez dzieci z lekką niepełnosprawnością intelektualną poziom myślenia uniemożliwiający odbiór informacji abstrakcyjnych, ograniczenia w zakresie analizy, syntezy, abstrahowania i uogólniania, a także zaburzenia $\mathrm{w}$ zakresie spostrzegania, uwagi, pamięci i mowy będzie przyczyniał się do uboższej percepcji i konceptualizacji wiedzy o emocjach. Przy czym, proces konceptualizacji wymagający wyższych procesów myślowych będzie jeszcze bardziej ograniczony.

\section{Smutek, emocja podstawowa negatywna}

Smutek należy do grona emocji podstawowych o walencji negatywnej ${ }^{48}$. W związku z czym charakteryzują go następujące cechy emocji podstawowych, jak: obecność u innych naczelnych, wywoływanie specyficznej reakcji fizjologicznej, poprzedzenie powszechnymi wydarzeniami, manifestacja spójnych autonomicznych i ekspresywnych reakcji, szybkie pojawianie się, krótkotrwałość, generowanie automatycznej oceny bodźca i doświadczanie jako wydarzenia, które zachodzi poza pełną kontrolą oraz pełni znaczącą funkcję adaptacyjną ${ }^{49}$. Wywoływany jest przez „nieodwracalną stratę" ${ }^{50} \mathrm{czy}$ „niepowodzenie głównego planu lub utratę aktywnego celu” ${ }^{51}$ i uruchamia zachowania jednostki związane z nierobieniem niczego lub poszukiwaniem nowego celu lub szukania pomocy. Smutek jest identyfikowany jako konsekwencja niepowodzenia, które dotknęło nas samych ${ }^{52}$. Im większe znaczenie ma niepowodzenie dla jednostki, tym odczucie smutku jest intensywniejsze.

Stopień integracji osobowości determinuje rodzaj smutku i warunki jego wzbudzenia ${ }^{53}$. Smutek z poziomu najniższego jest wywoływany poprzez brak zaspokojenia potrzeb podstawowych, ból fizyczny i niemożność zaspokojenia instynktów. Smutek z poziomu II jest efektem izolacji od innych i brakiem możliwości w realizacji celów. Smutek poziomu III wynika z krytycz-

${ }^{48}$ B. Fehr, J.A. Russell, Concept of emotion viewed from a prototype perspective, Journal of Experimental Psychology General, 1994, 13, s. 464-486; J.H. Turner, J.E. Stets, Socjologia emocji, Warszawa 2009, s. 68-69.

49 P. Ekman, An argument for basic emotions, Cognition and Emotion, 1992, 6, s. 169-200.

${ }^{50}$ R. Lazarus, Uniwersalne zdarzenia poprzedzajace emocje, [w:] Natura emocji, red. P. Ekman, R.J. Davidson, Gdańsk 1998, s. 148.

${ }^{51}$ K. Oatley, P.N. Johnson-Laird, The communicative theory of emotions: Empirical tests, mental models, and implications fot social interaction, [w:] Striving and feeling: Interactions among goals, affect and self regulation, red. L.L. Martin, A. Tesser, New York 1995, s. 363-393.

52 A. Ben-Zev, The subtlety of emotions, Massachusetts 2000, s. 466.

${ }^{53}$ K. Dąbrowski, Multilevelness of emotional and instinctive functions, Lublin 1996. 
nej oceny siebie i swoich osiągnięć, braku zdolności lub postępu w realizacji celu. Na IV poziomie smutek powiązany jest z poczuciem nieadekwatności względem innych lub sytuacji, świadomości swoich ograniczeń dysproporcją między oczekiwaniami własnymi a otoczeniem. Na najwyższym poziomie smutek jest konsekwencją doświadczanej rozbieżności między ja realnym a idealnym, dylematów egzystencjalnych. Kiedy człowiekowi jest smutno, jego system poznawczo-motoryczny ulega spowolnieniu i wycofaniu, co między innymi ma służyć skłonieniu kogoś do rezygnacji z celu, którego nie można przywrócić ${ }^{54}$. Funkcja adaptacyjna smutku jest rozumiana jako skłonienie osoby do uświadomienia sobie swoich wartości i zachowaniu ich ${ }^{55}$. Smutek i inne emocje $z$ tego klastra, jak na przykład przygnębienie czy rozpacz analizuje się bardzo często w kontekście zaburzeń afektywnych, takich jak depresja czy dystymia, w których to zaburzenia pogłębione przeżywanie takich emocji jest identyfikowane jako objaw chorobowy ${ }^{56}$.

Charakter doświadczeń emocjonalnych w dużej mierze może być kształtowany przez system poznawczy, czego z powodzeniem dowodzą tradycyjne badania nad optymistycznym vs pesymistycznym stylem wyjaśniania ${ }^{57}$ czy współczesne nad psychiczną konstrukcją emocji. Konstruktywny model emocji zakłada, że wiedza o emocjach ma znaczący udział w tworzeniu przeżycia emocjonalnego ${ }^{58}$. W skrócie rzecz ujmując, przeżycie emocji jest aktem kategoryzacji doznań afektywnych, kierowanym przez ucieleśnioną wiedzę o emocjach. W ujęciu tym emocje są jak akty percepcji polegające na interpretacji dynamicznych danych sensorycznych z użyciem danych pamięciowych $^{59}$. Powstanie emocji polega na tym, że doznanie o określonej walencji i pobudzeniu zostaje automatycznie i bezwysiłkowo skategoryzowane przez pojęciowy system emocji jako odrębna emocja. Ów pojęciowy system jest magazynem wiedzy pojęciowej na temat emocji utrwalonej w języku, która jest ukształtowana przez wcześniejsze doświadczenia. System zawiera bogate kontekstowo-specyficzne pojęcia poszczególnych emocji. Jednostka nie po-

${ }^{54}$ K. Oatley, J.M. Jenkins, Zrozumieć emocje, Warszawa 2003, s. 256-257.

55 A. Ben-Zev, The subtlety of emotions, s. 466.

${ }^{56}$ B. Gawda, Ekspresja pojeć afektywnych w narracjach osób z osobowościa antyspołeczna, Lublin 2007.

57 M.E.P. Seligman, Optymizmu można się nauczyć, Poznań 2010.

${ }^{58}$ L.F. Barrett, Constructing emotion, Psychological Topics, 2011, 3, s. 359-380.

${ }^{59}$ L.F. Barrett, Feeling is perceiving: Core affect and conceptualization in the experience of emotion, [w:] Emotions: Conscious and unconscious, red. L.F. Barrett, P.M. Niedenthal, P. Winkielman, New York 2005, s. 255-284; L.F. Barrett, Solving the emotion paradox: Categorization and the experience of emotion, Personality and Social Psychology Review, 2006, 10, s. 20-46; L.F. Barrett, The future of psychology: Connecting mind to brain, Perspectives in Psychological Science, 2009, 4, s. 326-339; L.F. Barrett, Constructing emotion, s. 359-380; L.F. Barrett, K. Lindquist, M. Gendron, Language as a context for emotion perception, Trends in Cognitive Sciences, 2007, 11, s. 327-332; L.F. Barrett i in., The experience of emotion, Annual Review of Psychology, 2007, 58, s. 373-403. 
siada zatem jednego pojęcia, na przykład smutku, ale całą kolekcję interpretacji, które może dopasowywać w zróżnicowany i elastyczny sposób.

Przedstawione powyżej przesłanki pokazują, że procesy poznawcze oraz precyzyjniej poziom rozwoju intelektualnego jednostki może mieć wpływ na wzbudzanie i doświadczanie smutku zapośredniczony wiedzą na jego temat. W związku z tym podjęto badania wśród dzieci z lekką niepełnosprawnością intelektualną oraz $\mathrm{w}$ normie intelektualnej mające na celu porównanie wiedzy na temat smutku manifestowanej w obrębie trzech kodów obrazowego, werbalnego i abstrakcyjnego aplikowanych w obrębie trzech funkcji - percepcji, wyrażania i rozumienia. Przyjęto założenie, że dzieci z lekką niepełnosprawnością intelektualną będą miały mniej rozbudowaną wiedzę o emocjach, ponieważ wymaga ona zaangażowania czynności poznawczych $\mathrm{i}$ instrumentalnych, które u tych dzieci są zaburzone.

Zaprezentowane w dalszej części artykułu badanie opiera się na propozycji teoretycznej psychicznej reprezentacji emocji, która z powodzeniem została wykorzystana do badań nad wiedzą emocjonalną dzieci w normie intelektualnej ${ }^{60}$.

\section{Metoda}

Uczestnicy. W badaniach własnych, w których analizie poddano umiejętność odczytywania emocji uczniów z lekką niepełnosprawnością intelektualną zastosowano dobór losowy. Kryteria doboru do grupy badanej właściwej były następujące:

- orzeczenie o potrzebie kształcenia specjalnego z powodu lekkiej niepełnosprawności intelektualnej (w orzeczeniu obowiązuje stare nazewnictwo: upośledzenie umysłowe w stopniu lekkim);

- brak sprzężeń występowania zdiagnozowanych zaburzeń ruchowych, sensorycznych, czy zaburzeń ze spektrum autystycznego;

- wiek dziecka w przedziale od 8-10 lat;

- realizacja kształcenia na terenie miasta (powyżej 20 tys. mieszkańców) województwa wielkopolskiego.

Kryteria te były warunkiem odpowiedniego doboru próby badanej i wyeliminowania zmiennych mogących zmniejszyć rzetelność prowadzonych badań. Kryterium braku występowania sprzężeń służyło ograniczeniu dodatkowych czynników mających wpływ na funkcjonowanie emocjonalne dziecka. W stosunku do dzieci wylosowanych z bazy Systemu Informacji Oświato-

${ }^{60}$ B. Górecka-Mostowicz, Co dzieci wiedza o emocjach; A. Jasielska, M. Buchnat, Knowledge about the joy in children with mild intellectual disability, Polish Psychological Bulletin, 2017, 48(2), s. 154-166; M. Stępień-Nycz, Rozwój reprezentacji emocji. 
wej (SIO) stosowano następującą procedurę: kontaktowano się z dyrektorem szkoły, prosząc o wyrażenie zgody na przeprowadzenie badań, następnie $\mathrm{w}$ celu zweryfikowania i uszczegółowienia informacji o dziecku zadawano pytania potwierdzające: stopień niepełnosprawności intelektualnej, występowanie dodatkowych sprzężeń lub ich brak. Po uzyskaniu zgody od dyrektora szkoły na przeprowadzenie badań i potwierdzeniu spełniania przez ucznia przyjętych kryteriów, proszono rodziców lub prawnych opiekunów dziecka o wyrażenie zgody na jego uczestnictwo w badaniach. Ogółem badaniami objęto 30 uczniów z lekką niepełnosprawnością intelektualną, w tym 15 dziewczynek i 15 chłopców w wieku 8-9 lat $(M=8,72 ; S D=0,44)$. Uczestnikami grupy kontrolnej było 30 uczniów w normie intelektualnej, którzy realizowali kształcenie powszechne na terenie miasta (powyżej 20 tys. mieszkańców) województwa wielkopolskiego. W grupie było 15 dziewczynek i 15 chłopców w wieku 8-10 lat $(M=8,81 ; S D=0,44)$, [t $(58)=0,84 ; p=n s]$.

Kryteria doboru do grupy kontrolnej były następujące:

- norma intelektualna;

- wiek dziecka w przedziale od 8-10 lat;

- realizacja kształcenia na terenie miasta (powyżej 20 tys. mieszkańców) województwa wielkopolskiego.

Charakterystykę badanej grupy kryterialnej oraz kontrolnej ze względu na płeć i wiek przedstawia tabela 1 .

Tabela 1

Struktura badanej grupy ze względu na płeć i wiek

\begin{tabular}{|c|c|c|c|c|}
\hline \multirow{2}{*}{$\begin{array}{c}\text { Wiek } \\
\text { badanych } \\
\text { dzieci }\end{array}$} & \multicolumn{2}{|c|}{ Grupa kryterialna } & \multicolumn{2}{c|}{ Grupa kontrolna } \\
\cline { 2 - 5 } & dziewczynka & chłopiec & dziewczynka & chłopiec \\
\hline 8 lat & 3 & 7 & 5 & 4 \\
\hline 9 lat & 12 & 8 & 10 & 11 \\
\hline Ogółem & 15 & 15 & 15 & 15 \\
\hline
\end{tabular}

Źródło: opracowanie własne na podstawie badań.

Narzędzie. Do pomiaru dziecięcej wiedzy o radości zastosowano autorskie narzędzie składające się z dziewięciu zadań o charakterze odpowiedzi zamkniętym i otwartym ${ }^{61}$. W artykule został przedstawiony wycinek badań

${ }^{61}$ A. Jasielska, M. Buchnat, Badanie wiedzy o emocjach dzieci z niepetnosprawnościa intelektualna - doniesienie wstępne, XXIII Ogólnopolska Konferencja Psychologii Rozwojowej „Zmiany rozwojowe w biegu życia: konteksty i perspektywy", Lublin, 28-30 maja 2014 r.; M. Buchnat, A. Jasielska, Inne emocje - poznawcza reprezentacja emocji dziecka z lekka niepetnosprawnościa intelektualna, VII Ogólnopolska Konferencja „Miejsce Innego we współczesnych naukach 


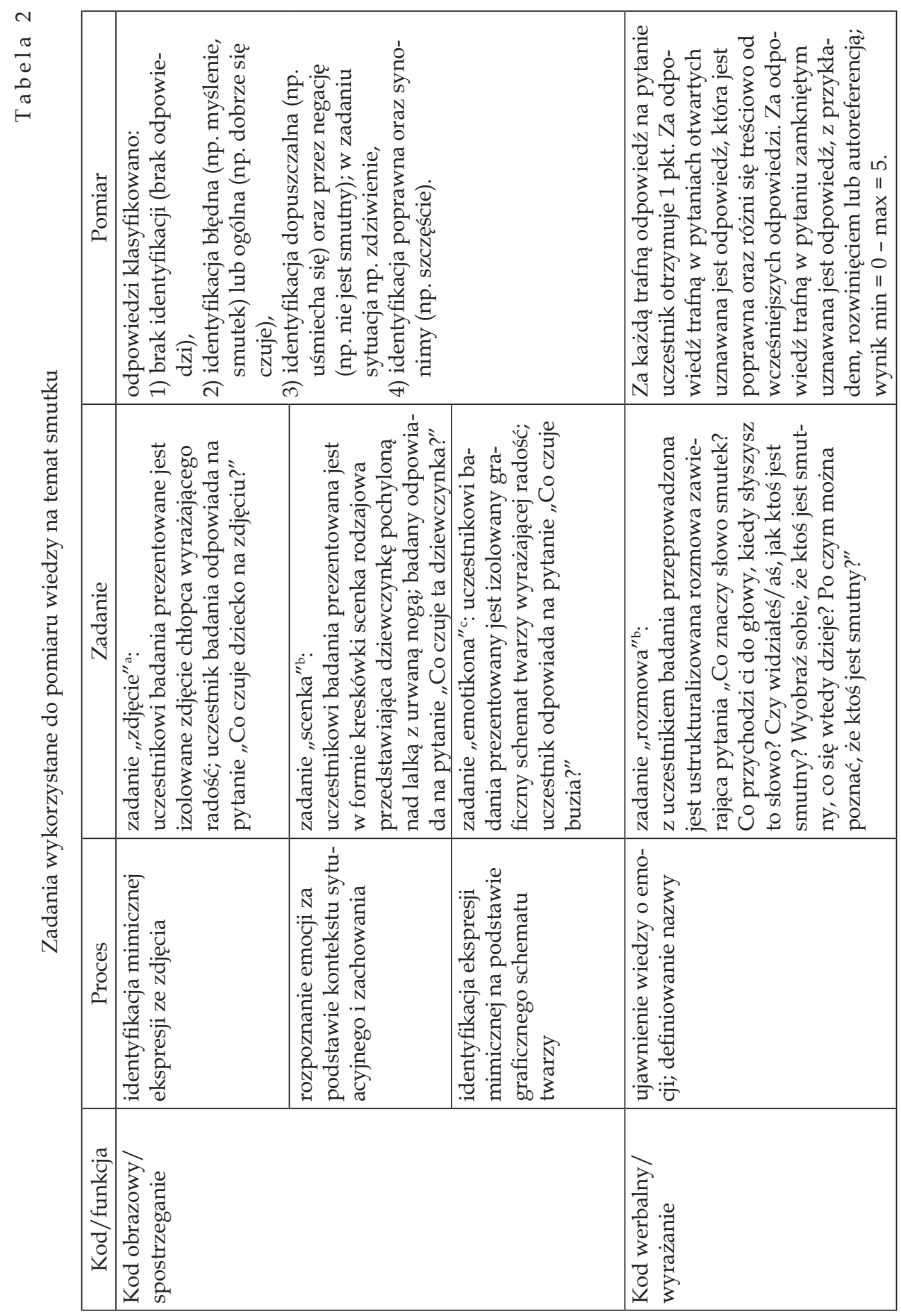




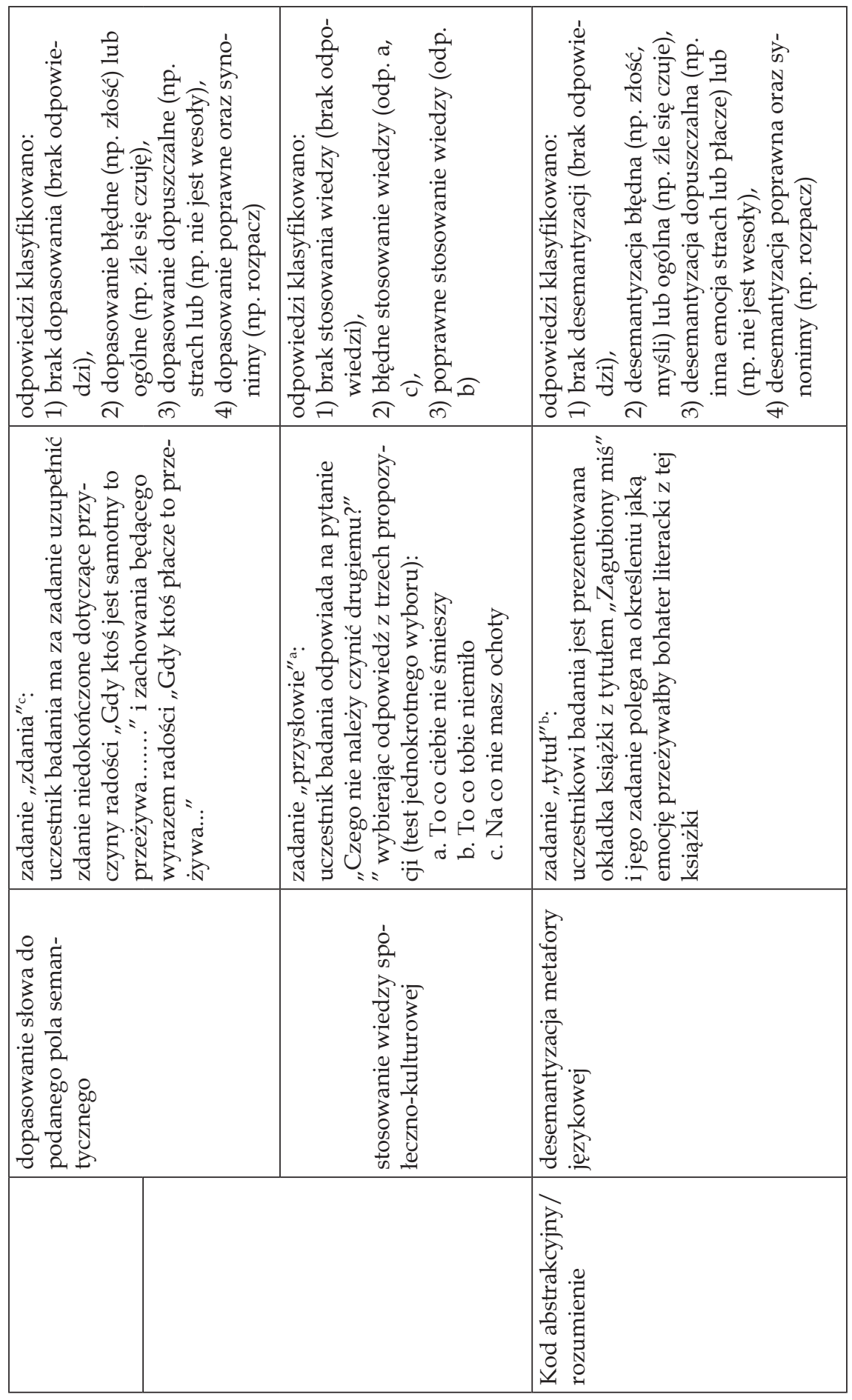




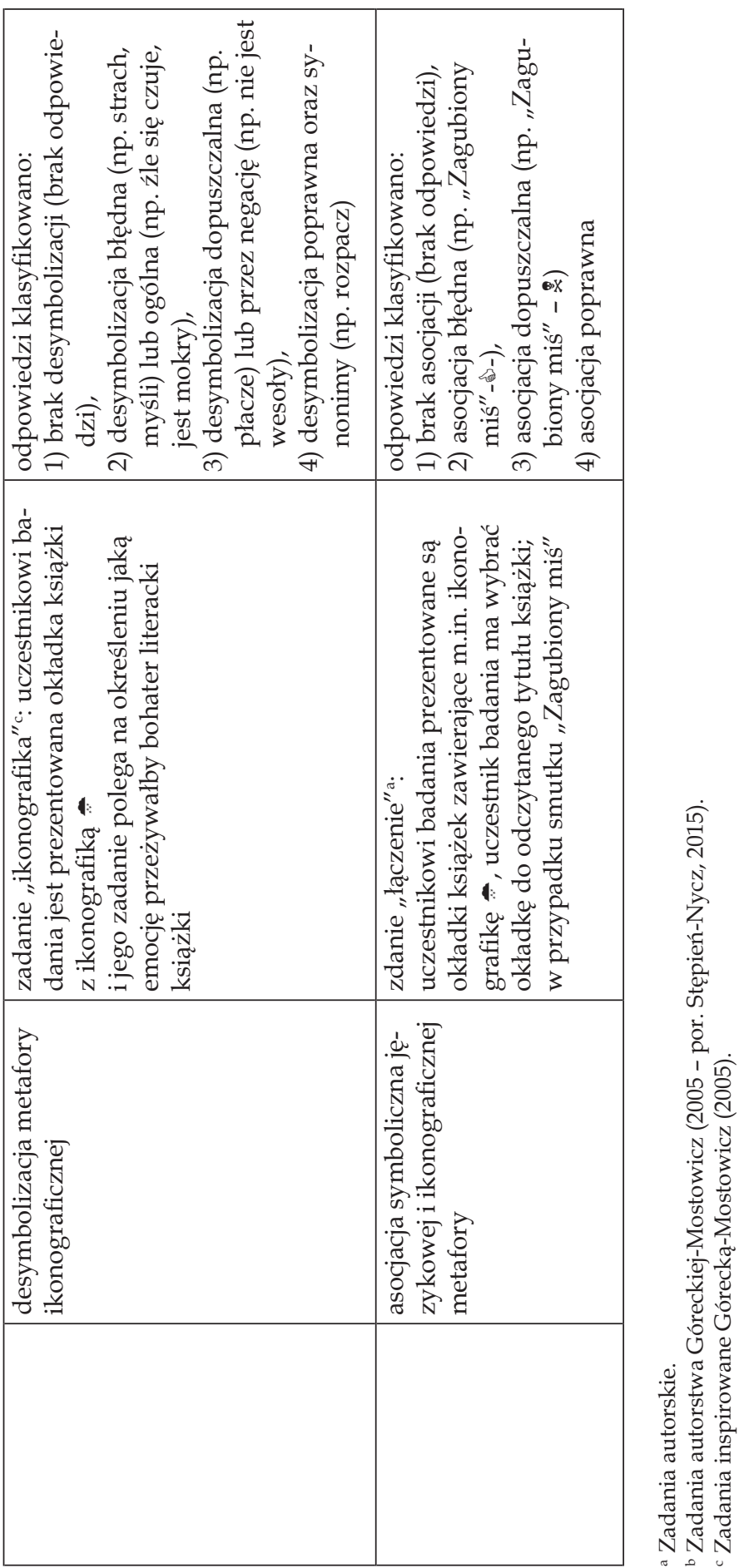


dotyczący emocji smutku. Cała bateria służy do pomiaru wiedzy na temat 6 emocji podstawowych (radości, smutku, strachu, wstrętu, zdziwienia, złości) i składa się z 54 zadań. Poszczególne zadania dla smutku wykorzystujące określone kody i funkcje wiedzy oraz sposób ich pomiaru przedstawia tabela 2.

Procedura. Badanie realizowano podczas dwóch spotkań, których długość zależała od tempa pracy badanego (każde ze spotkań trwało ok. $50 \mathrm{~min}$.). W każdym dniu badań zadania, które wykonywało dziecko były reprezentatywne dla każdego z trzech kodów: obrazowego, werbalnego i abstrakcyjnego. Kolejność zadań dobrano tak, aby badanie było dla dziecka atrakcyjne ze względu na zmieniający się materiał i formę odpowiedzi. Każde zadanie było najpierw przykładowo demonstrowane dziecku, w celu upewnienia się, czy prawidłowo zrozumiało polecenie. $W$ trakcie pierwszego spotkania dzieci wykonywały następujące zadania: emotikona, scenka, rozmowa i tytuł. W drugim dniu realizowały zadania: zdjęcia, zdania, ikonografika, przysłowia, łączenie. Podczas rozmowy kierowanej, odpowiedzi nagrywano za pomocą dyktafonu.

Pomiar. W związku z tym, że większość zadań (poza zadaniem przysłowia) ma charakter odpowiedzi udzielanych przez uczestników otwarty, o ich ocenę poproszono trzech sędziów kompetentnych. Sędziowie będący psychologami i pedagogami specjalnymi zastosowali do oceny kryteria przedstawione w tabeli 1 . Zgodność między sędziami była zadowalająca i wynosiła Tau b Kendall min $_{1}=0,84 ; \mathrm{p}<0,001$ - Tau b Kendall max $_{1}=1 ; \mathrm{p}<0,001$.

\section{Wyniki}

\section{Analizy dla kodu obrazowego (funkcja spostrzegania)}

W zakresie identyfikacji mimicznej ekspresji smutku na zdjęciu oraz identyfikowanie mimicznej ekspresji smutku na podstawie zgrafizowanego schematu wyrazu twarzy nie zaobserwowano istotnej różnicy między badanymi grupami. Dzieci z lekką niepełnosprawnością intelektualną równie często jak dzieci w normie intelektualnej poprawnie identyfikowały smutną ekspresję mimiczną.

Natomiast, różnica między grupami w zakresie rozpoznania smutku na podstawie kontekstu sytuacyjnego i zachowania przedstawionego $\mathrm{w}$ formie kreskówkowej scenki rodzajowej była istotna $\chi^{2}(2, N=60)=9,23 ; p<0,01$. Siła

o wychowaniu. Krytyczna analiza", Poznań (Obrzycko), 15-16 kwietnia 2015 r.; A. Jasielska, M. Buchnat, Wiedza dzieci z lekką niepetnosprawnościa intelektualną na temat emocji - prezentacja narzędzia badawczego, VI Ogólnopolska Konferencja „Bliżej emocji”, Lublin, 11-12 czerwca 2015 r.; A. Jasielska, M. Buchnat, Królewna Śmieszka - dziecięca wiedza o radości zależna od poziomu rozwoju umystowego, II Konferencja Psychologii Pozytywnej, Poznań 12-14 maja 2016 r.; A. Jasielska, M. Buchnat, Knowledge about the joy in children, s. 154-166. 
związku między zmiennymi, V Cramera $=0,39 ; \mathrm{p}<0,01$, wskazuje na umiarkowaną zależność między stopniem niepełnosprawności intelektualnej a poprawnym rozpoznaniem smutku. Dzieci w normie intelektualnej znacznie częściej poprawnie rozpoznawały sytuację jako smutną, niż ich rówieśnicy z grupy kryterialnej (ryc. 1).

Przyjrzyj się obrazkowi i powiedz, co czuje ta dziewczynka?

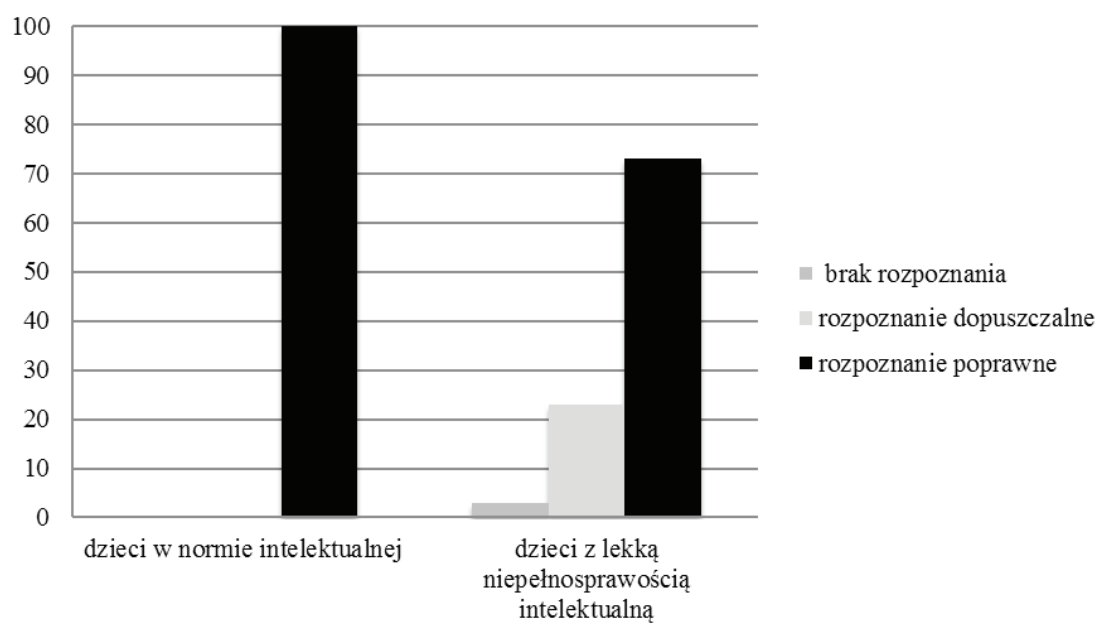

Ryc. 1. Różnice między grupami w zadaniu „scenka”

\section{Analizy dla kodu werbalnego (funkcja wyrażanie)}

Analiza testem $\mathrm{t}$ dla grup niezależnych wykazała, że dzieci z grupy kontrolnej ujawniają bogatszą wiedzę o smutku w rozmowie ukierunkowanej $(M=3,12 ; S D=0,78)$ niż dzieci z grupy kryterialnej $(M=1,84 ; S D=1,38)$, $\mathrm{t}(45,7)=4,43 ; p<0,001$. Wielkość efektu ( $d$ Cohena $=1,31)$ wskazuje na silny związek między poziomem rozwoju umysłowego a bogactwem prezentowanej wiedzy o smutku.

W zakresie ujawniania wiedzy o przyczynach smutku zaobserwowano różnice między grupami na granicy istotności statystycznej $\chi^{2}(2, N=60)$ $=5,49 ; p=0,06$. Natomiast, $\mathrm{w}$ zakresie wiedzy o zachowaniu różnica taka została zaobserwowana $\chi^{2}(2, N=60)=6,96 ; p<0,05$. Siła związku między zmiennymi, V Cramera $=0,34 ; p<0,05$, wskazuje na umiarkowaną zależność między sprawnością - niepełnosprawnością intelektualną a wiedzą na temat zachowania osoby przeżywającej smutek. Dzieci z lekką niepełnosprawnością intelektualną rzadziej niż dzieci w normie intelektualnej poprawnie dokańczały zdanie „Gdy ktoś płacze to przeżywa...”, co przedstawia rycina 2. 


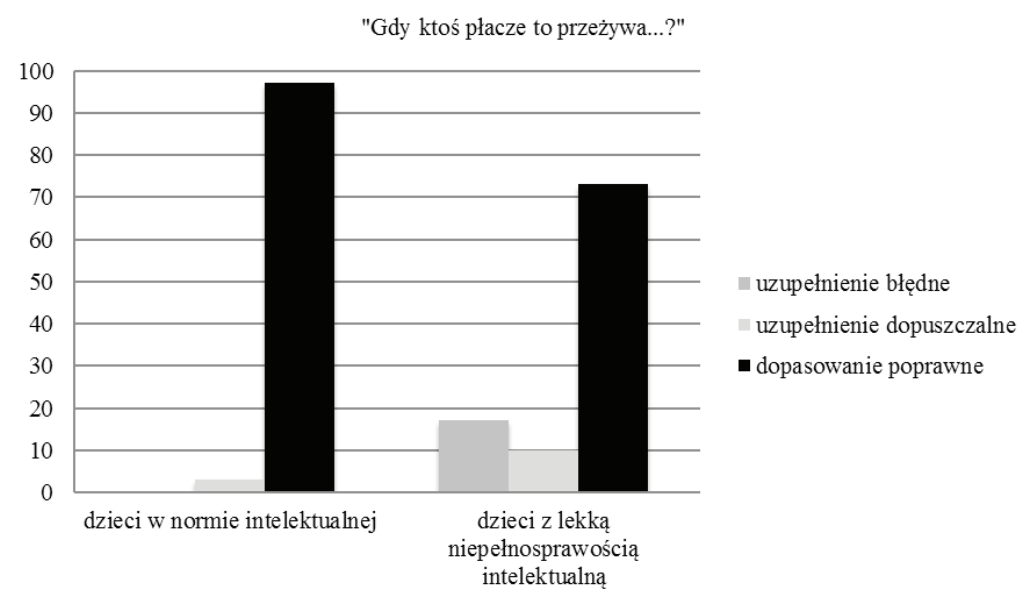

Ryc. 2. Różnice między grupami w zadaniu „zdania-zachowanie”

Różnica pomiędzy grupami w zakresie stosowanie wiedzy społeczno-kulturowej jest istotna $\chi^{2}(2, N=60)=10,26 ; p<0,01$. Siła związku między zmiennymi, V Cramer $=0,41 ; p<0,01$, wskazuje na umiarkowaną zależność między sprawnością - niepełnosprawnością intelektualną a poprawnym stosowaniem społeczno-kulturowej wiedzy dotyczącej smutku. Dzieci w normie intelektualnej znacznie częściej poprawnie odpowiadały na pytanie inspirowane przysłowiem, niż ich rówieśnicy z grupy kryterialnej, co przedstawia rycina 3.

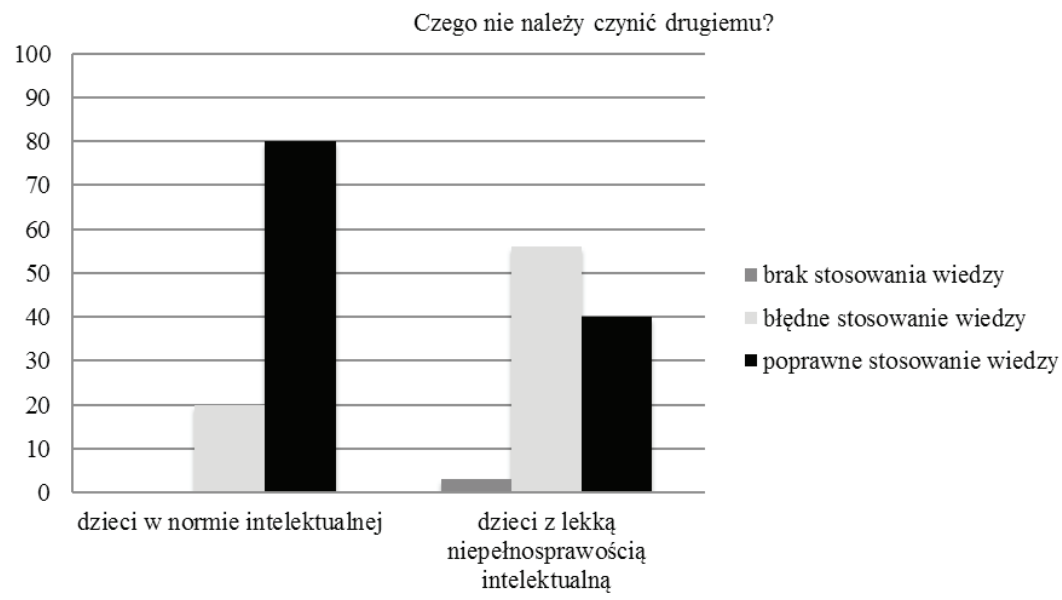

Ryc. 3. Różnice między grupami w zadaniu „przysłowie” 


\section{Analizy dla kodu abstrakcyjnego (funkcja rozumienie)}

Różnica pomiędzy grupami w zakresie desemantyzacji językowej metafory smutku jest istotna $\chi^{2}(2, N=60)=8,88 ; p<0,05$. Siła związku między zmiennymi, V Cramer $=0,38 ; p<0,05$, wskazuje na umiarkowaną zależność, między sprawnością - niepełnosprawnością intelektualną a poprawnym odczytaniem metafory językowej. Dzieci w normie intelektualnej znacznie częściej poprawnie dokonywały desemantyzacji, niż ich rówieśnicy z grupy kryterialnej, co ilustruje rycina 4.

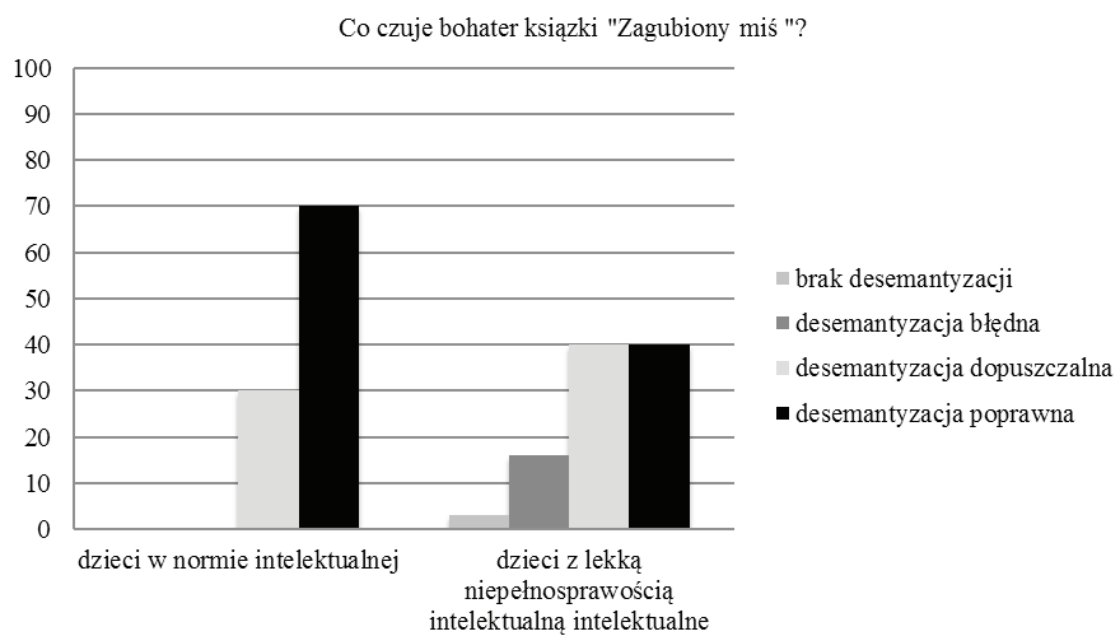

Ryc. 4. Różnice między grupami w zadaniu „tytuł”

Różnica pomiędzy grupami w zakresie desymbolizacji ikonograficznej metafory smutku jest istotna $\chi^{2}(3, N=60)=21,97 ; p<0,001$. Siła związku między zmiennymi, V Cramer $=0,6 ; p<0,001$, wskazuje na silną zależność między sprawnością - niepełnosprawnością intelektualną a poprawnym odczytaniem metafory wizualnej. Dzieci w normie intelektualnej znacznie częściej poprawnie dokonywały desymbolizacji, niż ich rówieśnicy z grupy kryterialnej, co przedstawia rycina 5.

W zakresie asocjacji symbolicznej dzieci z grupy kryterialnej istotnie statystycznie częściej dokonywały niepoprawnego połączenia tytułu książki "Zagubiony miś" z okładką książki przedstawiającą symboliczną ikonografikę smutku - deszcz $-\chi^{2}(3, N=60)=7,56 ; p<0,05$. Siła związku między zmiennymi, V Cramer =0,35; $p<0,05$, wskazuje na umiarkowaną, między sprawnością - niepełnosprawnością intelektualną a poprawną asocjacją symboliczną. Częstotliwość poszczególnych połączeń w obu grupach przedstawia rycina 6. 


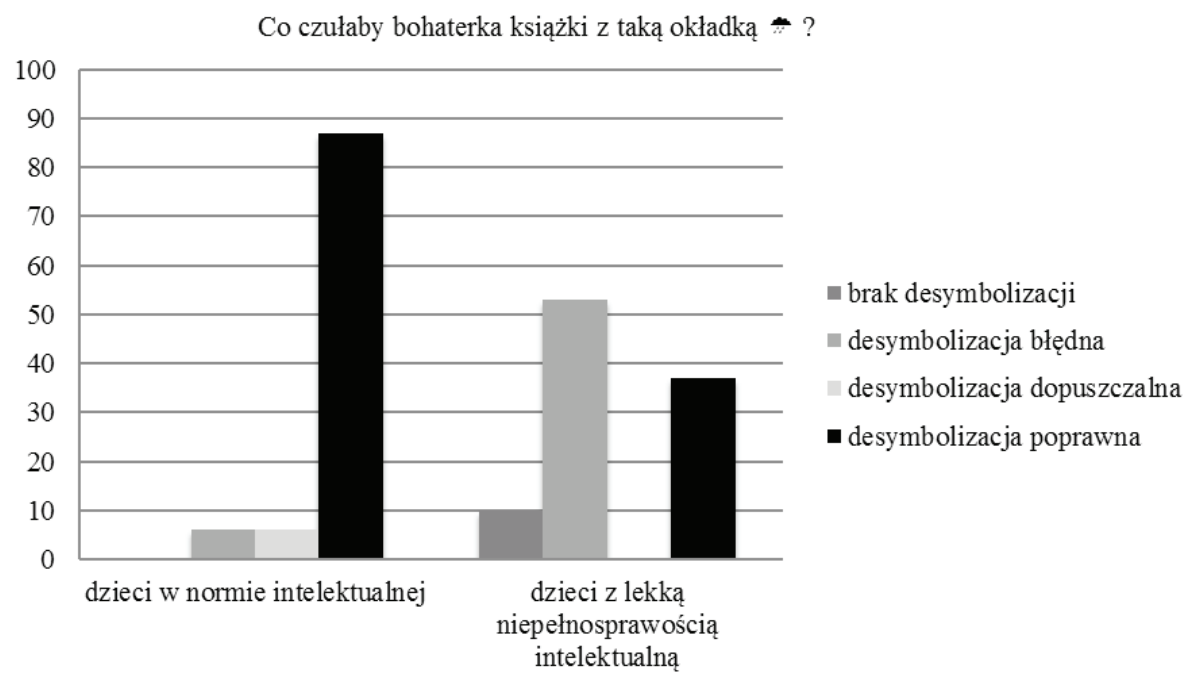

Ryc. 5. Różnice między grupami w zadaniu „ikonografika”

Jaką okładkę miałaby książka z tytułem "Zagubiony miś"?

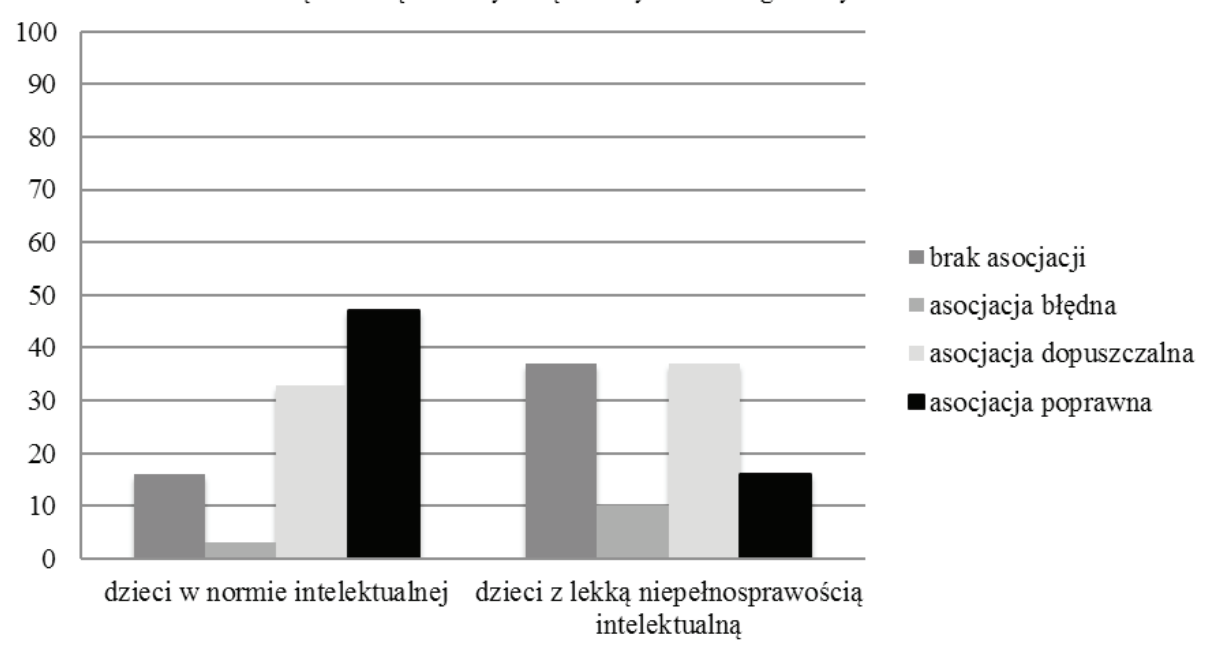

Ryc. 6. Różnice między grupami w zadaniu „łączenie” 


\section{Dyskusja}

Uzyskane wyniki wskazują jednocześnie na obecność i brak różnic w sposobie rozumienia smutku przez badane grupy. Zdecydowanie we wszystkich aspektach wiedzy dotyczącej smutku lepiej wypadają dzieci w normie intelektualnej. Jednak o kształcie wyników w dużej mierze decyduje poziom organizacji wiedzy na temat smutku i towarzyszące jemu operacje umysłowe. Zaobserwowane zależności są słabsze niż dla wiedzy o radości zdiagnozowanej z użyciem tego samego narzędzia dedykowanej tej emocji ${ }^{62}$.

W zakresie percepcji dzieci z lekką niepełnosprawnością intelektualną równie dobrze jak dzieci w normie intelektualnej radziły sobie z zadaniami, które polegały na identyfikacji mimiki smutku zarówno na realnym zdjęciu, jak i w graficznym schemacie twarzy. Dane te mogą świadczyć o łatwości w odczytywaniu smutku u innych osób, być może opartej na automatycznym procesie zarażenia afektywnego ${ }^{63}$ lub mentalizacji dotyczącej smutku czy empatii. Poprawność identyfikacji ekspresji mimicznej na podstawie emotikonów pomimo symbolicznej formy, może być związana z treningiem nazywania doświadczanej emocji z wykorzystaniem symbolu twarzy, który towarzyszy dziecku od edukacji przedszkolnej. Wczesny trening, konkretyzacja zadania, a także jego powtarzalność mogła przynieść tak dobry rezultat. Różnica, która pojawiła się między grupami w zakresie identyfikowania smutku w scence obyczajowej może być spowodowana trudnością powiązania kontekstu sytuacyjnego $\mathrm{z}$ daną emocją wynikającą z osiąganego poziomu myślenia, który warunkuje trudnościami z uogólnieniem ich wiedzy, wnioskowaniem przez analogię, sztywnością myślenia prowadzącą do stosowania znanych schematów w rozwiązywaniu nowych zadań. Uzasadnienia takie wydają się trafne, kiedy uwzględnimy fakt, że badane dzieci miały za zadanie wnioskować o smutku na podstawie statycznej kreskówki, a nie realnej, dynamicznej relacji interpersonalnej, co mogło stanowić trudność w wykonaniu zadania właśnie dla dzieci z lekką niepełnosprawnością intelektualną z racji obserwowanych u tej grupy problemów z dekontekstualizacją wiedzy. Dzieci z lekką niepełnosprawnością intelektualną mają problemy z określeniem związków wytworzonych w obrębie jednego układu sygnałów (postrzeganie) w drugim (werbalizacja), co skutkuje niskim poziomem współdziałania tych dwóch układów, prowadzącym do zwiększenia efektywności odbioru informacji w zakresie pierwszego układu sygnałów. Poglądowość operatyw-

${ }^{62}$ M. Buchnat, A. Jasielska, Inne emocje - poznawcza reprezentacja emocji dziecka z lekka niepetnosprawnościa intelektualna; A. Jasielska, M. Buchnat, Knowledge about the joy in children, s. 154-166.

63 M. Wróbel, Zarażanie afektywne. O procesie transferu emocji i nastroju między ludźmi, Warszawa 2016. 
na powoduje większe nieuporządkowanie informacji obniżając poziom percepcji ${ }^{64}$.

Można zatem stwierdzić, że kiedy przedmiotem porównania jest wiedza pochodząca z łatwo dostępnych przesłanek mających swe źródła w codziennym doświadczeniu uczestników badania (np. powszechna dostępność ekspresji mimicznych czy emotikon) możliwe jest wykorzystanie operacji konkretnych. Kiedy natomiast przedmiotem porównania staje się wiedza, której nie można bezpośrednio wywieść z materiału badawczego, tylko trzeba odwołać się do danych pozakontekstowych (np. osiągalnych zasobów pamięciowych $^{65}$ ), wówczas obserwuje się różnice między dziećmi, zależne od poziomu ich rozwoju intelektualnego.

$\mathrm{W}$ zadaniach $\mathrm{z}$ obszaru kodu werbalnego związek między poziomem rozwoju umysłowego a bogactwem prezentowanej wiedzy o smutku ujawnił wynik uzyskany w zadaniu „rozmowa”. Zaobserwowana rozbieżność pomiędzy dziećmi z lekką niepełnosprawnością intelektualną a dziećmi w normie intelektualnej wynika prawdopodobnie z różnic w zakresie wiedzy, zasobu słownictwa i fluencji na korzyść tych drugich. W zadaniu polegającym na uzupełnianiu zdań niedokończonych różnice wystąpiły zarówno w zdaniu dotyczącym zachowania, jak i przyczyny. Uzupełniając zdanie dotyczące przyczyny smutku, dzieci z lekką niepełnosprawnością intelektualną częściej niż dzieci w normie intelektualnej dokonywały uzupełnienia dopuszczalnego twierdząc, iż „Gdy ktoś jest samotny to przeżywa...." pustkę, samotność, złość lub lęk. Z kolei, zdanie na temat zachowania: „Gdy ktoś płacze to przeżywa..." częściej dokańczały w sposób niewłaściwy na przykład „chce iść do mamy”, „ucieka” lub dopuszczający „Lęk, złość".

Wydaje się, że z racji dominacji myślenia konkretnego dzieci z lekką niepełnosprawnością intelektualną częściej korzystają z modelu objawowego wiedzy o smutku ${ }^{66}$, który uwzględnia prototypowe współwystępujące manifestacje emocji pochodzące z aktów proksemicznych, mimiki twarzy, czy zachowań. Rzadziej natomiast wykorzystują bardziej zaawansowany poznawczo model przyczynowy, zgodnie z którym to właśnie przyczyna emocji jest właściwością, na podstawie której jednostka opiera swoje wyjaśnienia dotyczące korelacji poszczególnych elementów doświadczenia emocjonalnego ${ }^{67}$. W modelu przyczynowym za cechę centralną łączącą poszczególne elementy

${ }^{64}$ Z. Gajdzica, Edukacyjne konteksty bezradności społecznej, s. 70-71.

${ }^{65}$ M. Moore Channell, J.M. Barth, Individual differences in preschoolers' emotion content memory: The role of emotion knowledge, Journal of Experimental Child Psychology, 2013, 115(3), s. 552-561.

${ }^{66}$ I. Nowakowska-Kempna, Konceptualizacja uczuć w języku polskim, s. 366.

${ }^{67}$ W. Ahn i in., Causal Status as a Determinant of Feature Centrality, Cognitive Psychology, 2000, 41, s. 361-416; A. Jasielska, „Nie ma radości bez smutku” - porównanie reprezentacji emocji podstawowych, Czasopismo Psychologiczne, 2011, 17, s. 61-176; taże, Charakterystyka i konsekwencje; 
reprezentacji czy wiedzy o emocjach uznaje się przyczynę tylko wtedy, kiedy jednostka dysponuje wystarczająco rozwiniętymi procesami wnioskowania, które pozwalają jej stwierdzić, że na przykład smutek jest wywoływany "kiedy nie idzie mi tak jakbym chciał" (przykładowa wypowiedź badanego w normie intelektualnej), a nie "kiedy mama na mnie krzyczy” (przykładowa wypowiedź badanego z lekką niepełnosprawnością intelektualną).

W zakresie składnika konceptualnego wiedzy o smutku ujawnione różnice pomiędzy dziećmi z lekką niepełnosprawnością intelektualną i dziećmi $\mathrm{w}$ normie intelektualnej były na znacznie wyższym poziomie. $\mathrm{W}$ obszarze kodu abstrakcyjnego dzieci z lekką niepełnosprawnością intelektualną udzielały głównie błędnych odpowiedzi. Wyniki dotyczące zadania "przysłowie” ujawniły, że dzieci z lekką niepełnosprawnością intelektualną, albo nie posiadają albo nie potrafią spontanicznie zastosować wiedzy społeczno-kulturowej w sytuacji aluzyjnej. W zadaniu "tytuł" dzieci te dokonywały niepoprawnej desemantyzacji z racji ubogiego słownictwa, interpretując prawdopodobnie słowo „zagubiony" jako „zgubiony”, o czym świadczą wypowiedzi „Zgubiony miś czuje się dobrze, chciałbym się zgubić", "Boi się bo się zgubił”. Podobna sytuacja miała miejsce w zadaniu „ikonografika”, w którym dzieci z lekką niepełnosprawnością intelektualną najczęściej błędnie desymbolizowały emocje domniemanych bohaterów książek . Z kolei, w zadaniu "łączenie" równie często dzieci z lekką niepełnosprawnością nie dokonywały poprawnej asocjacji, chociaż część połączeń miała charakter dopuszczający. Różnice w obszarze konceptualizacji wiedzy pomiędzy dziećmi w normie intelektualnej a dziećmi z lekką niepełnosprawnością intelektualną są nie tylko większe, ale przede wszystkim na innym poziomie jakości tej wiedzy. Dzieci z lekką niepełnosprawnością intelektualną z racji na dostępny im poziom myślenia konkretnego słabiej poradziły sobie z zadaniami z zakresu kodu abstrakcyjnego wymagającego wyższego poziomu przetwarzania poznawczego. W związku z tym odpowiedzi, które udzielały w zakresie zadań z kodu abstrakcyjnego, były najczęściej uproszczeniem ich i odniesieniem do określonej sytuacji konkretnej.

Przyjęta w badaniu koncepcja kodów reprezentacji emocji znalazła swoje empiryczne potwierdzenie. Umożliwia ona ujęcie rozwojowe, zgodnie z którym osiąganie przez jednostkę kolejnych etapów rozwoju poznawczego prowadzi do posiadania bardziej rozbudowanej i elastycznej wiedzy o emocjach $^{68}$. Ta punktualność zmian rozwojowych wiąże się na przykład z momentem nabywania mowy czy osiągnięciem etapu myślenia abstrakcyjnego. U dzieci z lekką niepełnosprawnością intelektualną rozwój poznawczy jest

M. Siemer, Beyond prototypes and classical definitions: Evidence for a theory-based representation of emotion concepts, Cognition and Emotion, 2008, 22, s. 620-632.

68 T. Maruszewski, E. Ścigała, Poznawcza reprezentacja emocji, s. 245-278. 
spowolniony, co w rezultacie przyczyniło się do posiadania wiedzy o emocjach obfitującej w elementy konkretne. Pokazuje to także, że aby przechodzić między kodami i dokonywać ciągłej reinterpretacji znaczeń oraz zwiększać dostępność posiadanej wiedzy niezbędne są zaawansowane procesy poznawcze, które stanowią jej element strukturalny ${ }^{69}$. Potwierdzeniem aspektu rozwojowego koncepcji kodów emocji jest manifestowany przez dzieci z lekką niepełnosprawnością intelektualną model objawowy rozumienia emocji ${ }^{70}$. Model ten głosi, że obserwowalne przejawy emocji, takie jak mimika, pantomimika, czy proksemika są utożsamiane $\mathrm{z}$ istotą danej emocji. Ponieważ manifestowane przejawy emocji są łatwo dostępne percepcyjnie, to zgodnie $\mathrm{z}$ zasadą korespondencji te konkretne dane rejestrowane $\mathrm{w}$ kodzie obrazowym zostają uznane za daną emocję.

Należy przekreślić, że istnieje grupa dzieci z lekką niepełnosprawnością intelektualną, których wiedza na temat smutku jest na poziomie przyrównywalnym do wiedzy ich rówieśników w normie intelektualnej. Kolejną grupę stanowią dzieci, których wiedza na temat smutku jest nieharmonijna i w niektórych obszarach poprawna, a w innych wystarczająco poprawna. Dzieci te prawdopodobnie przy odpowiednim wsparciu mogłyby wzbogacić wiedzę na temat tej emocji zgodnie ze sferą najbliższego rozwoju ${ }^{71}$. Pozostaje jednak grupa, która manifestuje znaczne braki w zakresie wiedzy o smutku. Niezależnie od poziomu wiedzy opierając się na zależności między pamięcią deklaratywną (tu: wiedza o smutku) a wiedzą proceduralną (np. strategie radzenia sobie ze smutkiem) wnioskiem płynącym dla praktyki społecznej byłaby oferta interwencji psychoedukacyjnych. W jej ramach chodziłoby o rozwijanie wiedzy o smutku, która mogłaby w krótkiej perspektywie czasowej przełożyć się na umiejętności radzenia sobie ze smutkiem, a w dalszej - na podwyższenie nastroju. Inicjatywy o takim charakterze są z powodzeniem podejmowane między innymi na gruncie terapii poznawczo-behawioralnej ${ }^{72}$. Działania o charakterze psychokorekcyjnym skoncentrowane na wiedzy o emocjach pod postacią tak zwanych schematów emocjonalnych ${ }^{73}$ mogą przyczynić się do efektywniejszych strategii regulacji emocji. W przypadku dzieci z lekką niepełnosprawnością intelektualną interwencje powinny być oparte na materiale konkretnym i dużej liczbie powtórzeń, które pozwolą im uwewnętrznić skrypty działań.

${ }^{69}$ M. Stępień-Nycz, Rozwój reprezentacji emocji, s. 37.

${ }^{70}$ I. Nowakowska-Kempna, Konceptualizacja uczuć w języku polskim, s. 366.

${ }^{71}$ S. Wygotski, Myślenie i mowa, Warszawa 1989.

${ }^{72}$ L. Crutchley, Jak być szczęśliwym (albo chociaż mniej smutnym), Kraków 2015; B. Górecka-Mostowicz, Co dzieci wiedzq o emocjach; P. Stallard, Czujesz tak, jak myślisz, Poznań 2006.

${ }^{73}$ R.L. Leahy, Techniki Terapii Poznawczej, Kraków 2008; R.L. Leahy, D. Tirch, L.A. Napolitano, Regulacja emocji w psychoterapii, Kraków 2014. 
Wydaje się, że silną stroną zastosowanej procedury badawczej jest skonstruowanie narzędzia, które pozwala rejestrować spontaniczne zachowania badanego zbliżone do jego codziennej aktywności. Minusem z kolei jest czasochłonność badania, która u niektórych badanych z niepełnosprawnością prowadziła do zniechęcenia ${ }^{74}$. Choć badanie w konstrukcji swojej odwołuje się do trzech różnych kodów reprezentacji, to w przewadze korzysta z wypowiedzi językowej, co jest zjawiskiem powszechnym w badaniach nad wiedzą emocjonalną ${ }^{75}$, choć nie jedynym (por. strategie rekomendowane do pomiaru skryptów emocjonalnych ${ }^{76}$ ). Na przykład, w badaniach metaforycznego rozumienia emocji zastosowano między innymi rysunek ${ }^{77}$, a w teście wiedzy o emocjach wyrażanie emocji ekspresją mimiczną ${ }^{78}$. Techniki te jednoznacznie wykraczały poza językowy obraz świata i ich zastosowanie można rozważyć jako modyfikację warsztatową w przyszłych badaniach. Ponadto, nowym obszarem penetracji teoretycznej i empirycznej mogłyby być różnice indywidualne w zakresie wiedzy o smutku. Ponieważ rozwój ma charakter ekwifinalny ${ }^{79}$, to tylko analiza indywidualnych trajektorii rozwojowych pozwoliłaby określić między innymi, jaki udział w kształtowaniu wiedzy o smutku u dzieci z lekką niepełnosprawnością intelektualną ma środowisko rodzinne czy edukacja szkolna.

\section{BIBLIOGRAFIA}

Ahn W., Kim N.S., Lassaline M.E., Dennis M.J., Causal Status as a Determinant of Feature Centrality, Cognitive Psychology, 2000, 41.

Abbeduto L., Davies B., Furman L., Solesby S.P., Identifying the referents of spoken messages: The use of context and classification requests by children with mental retardation and by non retarded children, American Journal on Mental Retardation, 1991, 93.

Abbeduto L., Nuccio J., Dynamic contextual variables and the directives of person with mental retardation, American Journal on Mental Retardation, 1993, 5.

Barrett L.F., Feeling is perceiving: Core affect and conceptualization in the experience of emotion, [w:] Emotions: Conscious and unconscious, red. L.F. Barrett, P.M. Niedenthal, P. Winkielman, Guilford, New York 2005.

Barrett L.F., Solving the emotion paradox: Categorization and the experience of emotion, Personality and Social Psychology Review, 2006, 10.

${ }^{74}$ M. Pytel, Rozumienie emocji przez osoby z niepetnosprawnościa intelektualną w stopniu umiarkowanym, Poznań 2016.

${ }_{75}$ B. Gawda, Ekspresja pojęć afektywnych; A. Jasielska, Charakterystyka i konsekwencje; B. Gawda, Struktura pojęć emocjonalnych. Wykorzystanie technik fluencji werbalnej, Lublin 2017.

${ }_{76}$ C. Saarni, The development of emotional competence, New York 1999, s. 149.

${ }_{77}$ M. Wiśniewska-Kin, „Miłość jest jak wiatrak“.

${ }^{78}$ M. Stępień-Nycz, Rozwój reprezentacji emocji.

${ }^{79}$ J. Trempała, Mechanizm zmiany rozwojowej, [w:] Psychologia rozwoju człowieka, red. J. Trempała, Warszawa 2011, s. 50-70. 
Barrett L.F., The future of psychology: Connecting mind to brain, Perspectives in Psychological Science, 2009, 4 .

Barrett L.F., Constructing emotion, Psychological Topics, 2011, 3.

Barrett L.F., Lindquist K., Gendron M., Language as a context for emotion perception, Trends in Cognitive Sciences, 2007, 11.

Barrett L.F., Mesquita B., Ochsner K.N., Gross J.J., The experience of emotion, Annual Review of Psychology, 2007, 58.

Ben-Zev A., The subtlety of emotions, A Bradford Book, Massachusetts 2000.

Brenner E.M., Salovey P., Regulacja emocjonalna w okresie dzieciństwa: aspekty rozwojowe, interpersonalne i indywidualne, [w:] Rozwój emocjonalny a inteligencja emocjonalna, red. P. Salovey, D.J. Sluyter, Dom Wydawniczy Rebis, Poznań 1999.

Bucci W., The Need for a "Psychoanalytic Psychology" in the Cognitive Science Field, Psychoanalytic Psychology, 2000, 17.

Bucci W., The interplay of subsymbolic and symbolic processes in psychoanalytic treatment, Psychoanalytic Dialogues, 2005, 15.

Buchnat M., Formy organizacji kształcenia dziecka z lekka niepetnosprawnościa intelektualna, Wydawnictwo Naukowe UAM, Poznań 2015.

Buchnat M., Jasielska A., Inne emocje - poznawcza reprezentacja emocji dziecka z lekka niepetnosprawnościa intelektualna, VII Ogólnopolska Konferencja „Miejsce Innego we współczesnych naukach o wychowaniu. Krytyczna analiza", Poznań (Obrzycko), 15-16 kwietnia $2015 \mathrm{r}$.

Cebula K.R., Wishart J., Social cognition in children with Down syndrome, International Review of Research in Mental Retardation, 2008, 35.

Cebula K.R., Moore D.G., Wishart J.G., Social cognition in children with Down's syndrome: Challenges to research and theory building, Journal of Intellectual Disability Research, 2006,54 .

Chrzanowska I., Funkcjonowanie dzieci upośledzonych umystowo w stopniu lekkim w szkole podstawowej, Wydawnictwo UŁ, Łódź 2003.

Crutchley L., Jak być szczęśliwym (albo chociaż mniej smutnym), Wydawnictwo Otwarte, Kraków 2015.

Dąbrowski K., Multilevelness of emotional and instinctive functions, Towarzystwo Naukowe KUL, Lublin 1996.

Duszak A., O emocjach bez emocji. Gniew w perspektywie lingwistycznej, [w:] Anatomia gniewu. Emocje negatywne w językach i kulturach świata, red. A. Duszak N. Pawlak, Wydawnictwa UW, Warszawa 2003.

Ekman P., An argument for basic emotions, Cognition and Emotion, 1992, 6.

Fehr B., Russell J.A., Concept of emotion viewed from a prototype perspective, Journal of Experimental Psychology General, 1994, 13.

Fidler D.J., The emergence of a syndromespecific personality profile in young children with Down syndrome, Down Syndrome Research and Practice, 2006, 10(2).

Fernandez-Dols J.-M., Bachorowski J.-A., Emotions. Encyclopedia of psychological Assessment, SAGE Publications 2003, http://www.sageereference.com/psychaassessment/Article_n76.html., [dostęp: 12.01.2018].

Gajdzica Z., Edukacyjne konteksty bezradności społecznej osób z lekkim upośledzeniem umystowym, Wydawnictwo UŚ, Katowice 2007.

Gawda B., Ekspresja pojęć afektywnych w narracjach osób z osobowościa antyspołeczna, Wydawnictwo UMCS, Lublin 2007.

Gawda B., Struktura pojęć emocjonalnych. Wykorzystanie technik fluencji werbalnej, Wydawnictwo UMCS, Lublin 2017. 
Głodkowska J., Poznanie ucznia szkoty specjalnej, WSiP, Warszawa 1999.

Górecka-Mostowicz B., Co dzieci wiedzą o emocjach, Wydawnictwo Naukowe UP, Kraków 2005.

Grabias S.P., Jezyk w zachowaniach społecznych, Wydawnictwo UMCS, Lublin 2001.

Heider F., The psychology of interpersonal relationships, Wiley, New York 1958.

Jasielska A., "Nie ma radości bez smutku” - porównanie reprezentacji emocji podstawowych, Czasopismo Psychologiczne, 2011, 17.

Jasielska A., Charakterystyka i konsekwencje potocznego rozumienia emocji, Wydawnictwo Naukowe UAM, Poznań 2013.

Jasielska A., Buchnat M., Badanie wiedzy o emocjach dzieci z niepetnosprawnościa intelektualna doniesienie wstępne, XXIII Ogólnopolska Konferencja Psychologii Rozwojowej „Zmiany rozwojowe w biegu życia: konteksty i perspektywy", Lublin 28-30 maja 2014 r.

Jasielska A., Buchnat M., Wiedza dzieci z lekka niepetnosprawnościa intelektualną na temat emocji - prezentacja narzędzia badawczego, VI Ogólnopolska Konferencja „Bliżej emocji”, Lublin 11-12 czerwca 2015 r.

Jasielska A., Buchnat M., „Królewna Śmieszka” - dziecięca wiedza o radości zależna od poziomu rozwoju umystowego, II Konferencja Psychologii Pozytywnej, Poznań 12-14 maja 2016 r.

Jasielska A., Buchnat M., Knowledge about the joy in children with mild intellectual disability, Polish Psychological Bulletin, 2017, 48(2).

Jęczeń U., Uwarunkowania rozwoju kompetencji językowej i komunikacyjnej u dzieci upośledzonych umystowo, Logopedia, 2003, 32.

Karmiloff-Smith A., Beyond modularity: A developmental perspective on cognitive science, MIT Press, Cambridge 1995.

Kijewska M., O możliwościach usprawniania pamięci dzieci z niepetnosprawnością intelektualna w stopniu lekkim, [w:] Nauczanie uczniów z niepetnosprawnością intelektualna w stopniu lekkim, red. S.P. Sadowska, Akapit, Torun 2006.

Kościelak R., Psychologiczne podstawy upośledzonych umystowo, Wydawnictwo Naukowe PWN, Warszawa 1989.

Kościelska M., Oblicza upośledzenia, Wydawnictwo Naukowe PWN, Warszawa 1998.

Lazarus R., Uniwersalne zdarzenia poprzedzające emocje, [w:] Natura emocji, red. P. Ekman, R.J. Davidson, GWP, Gdańsk 1998.

Leahy R.L., Techniki Terapii Poznawczej, Wydawnictwo UJ, Kraków 2008.

Leahy R.L., Tirch D., Napolitano L.A., Regulacja emocji w psychoterapii, Wydawnictwo UJ, Kraków 2014.

Maruszewski T., Ścigała E., Poznawcza reprezentacja emocji, Przegląd Psychologiczny, 1995, 38.

Maruszewski T., Ścigała E., Emocje - aleksytymia - poznanie, Humaniora, Poznań 1998.

Moore Channell M., Barth J.M., Individual differences in preschoolers' emotion content memory: The role of emotion knowledge, Journal of Experimental Child Psychology, 2013, $115(3)$.

Nęcka E., Inteligencja: geneza - struktura - funkcje, GWP, Gdańsk 2003.

Niedenthal P.M., Emotion Concepts, [w:] Handbook of Emotions, red. M. Lewis, J.M. HavilandJones L.F. Barrett, The Guilford Press, New York 2008.

Nowakowska-Kempna I., Konceptualizacja uczuć w języku polskim. Część II. Data, Wydawnictwo WSP, Warszawa 2000.

Oatley K., Jenkins J.M., Zrozumieć emocje, Wydawnictwo Naukowe PWN, Warszawa 2003.

Oatley K., Johnson-Laird P. N., The communicative theory of emotions: Empirical tests, mental models, and implications fot social interaction, [w:] Striving and feeling: Interactions among goals, affect and self regulation, red. L.L. Martin, A. Tesser, Erlbaum, Hillsdale, New York 1995. 
Obuchowska I., Dzieci upośledzone w stopniu lekkim, [w:] Dziecko niepetnosprawne w rodzinie, red. I. Obuchowska, WSiP, Warszawa 1999.

Obuchowski K., Kody umystu i emocje, Wyższa Szkoła Humanistyczno-Ekonomiczna, Łódź 2004.

Odgen C.K., Richards I.A., The meaning of meaning, Harcourt Brace Jovanovich, Orlando 1989.

Oosterwijk S., Rotteveel M., Fischer A.H., Hess U., Embodied emotion concepts: How generating words about pride and disappointment influences posture, European Journal of Social Psychology, 2009, 39.

Parkinson B., Ideas and realites of emotion, Routledge, London 1995.

Piaget J., Inhelder B., Psychologia dziecka, Siedmioróg, Wrocław 1993.

Pilecka W., Psychoruchowy rozwój dzieci o obniżonej sprawności umystowej, [w:] Stymulacja psychoruchowego rozwoju dzieci o obniżonej sprawności umystowej, red. W. Pilecka, J. Pilecki, Wydawnictwo WSP, Kraków 2003.

Pużyński S., Wciórka J., Klasyfikacja Zaburzeń Psychicznych i Zaburzeń Zachowania ICD-10, Vesaliu, Kraków 2000.

Pytel M., Rozumienie emocji przez osoby z niepetnosprawnością intelektualna w stopniu umiarkowanym - niepublikowana praca magisterska, Instytut Psychologii UAM, Poznań 2016.

Rakowska A., Znajomość określonych grup stownictwa przez dzieci lekko upośledzonych umystowo, Szkoła Specjalna, 1980, 2.

Rakowska A., Język mówiony dzieci lekko upośledzonych umysłowo w sytuacji szkolnej, [w:] Dyskurs edukacyjny, red. T. Rittel, Wydawnictwo WSP, Kraków 1996.

Russell J.A., Lemay G., Emotion Concepts, [w:] Handbook of Emotions, red. M. Lewis, J.M. Haviland-Jones, The Guilford Press, New York 2000.

Saarni C., The development of emotional competence, The Guilford Press, New York 1999.

Seligman M.E.P., Optymizmu można się nauczyć, Wydawnictwo Media Rodzina, Poznań 2010.

Simeonsson R.J., Bailey D.R., Assessing Needs of Family with Handicapped Infants, Journal of Special Education, 1988, 22.

Siemer M., Beyond prototypes and classical definitions: Evidence for a theory-based representation of emotion concepts, Cognition and Emotion, 2008, 22.

Smith K., Social psychological perspectives on laypersons' theories of emotion, [w:] Everyday Conceptions of Emotion: An Introduction to the Psychology, Anthropology, and Linguistic of Emotion, red. J.A. Russell, J.-M. Fernandez-Dols, A.S.R. Manstead, J.C. Wellenkamp, Kluwer, Dordtrecht 1995.

Stallard P., Czujesz tak, jak myślisz, Zysk i S-ka Wydawnictwo, Poznań 2006.

Stefańska-Klar R., Późne dzieciństwo. Młodszy wiek szkolny, [w:] Psychologia rozwoju człowieka, red. B. Harwas-Napierała, J. Trempała, t. 2, Wydawnictwo Naukowe PWN, Warszawa 2005.

Stępień-Nycz M., Rozwój reprezentacji emocji w dzieciństwie, Liberi Libri, Warszawa 2015.

Stallard P., Czujesz tak, jak myślisz, Zysk i S-ka Wydawnictwo, Poznań 2006.

Szumska D., O emocjach bez emocji, Język a Kultura, 2000, 14.

Trempała J., Mechanizm zmiany rozwojowej, [w:] Psychologia rozwoju człowieka, red. J. Trempała, Wydawnictwo Naukowe PWN, Warszawa 2011.

Turner J.H., Stets J.E., Socjologia emocji, Wydawnictwo Naukowe PWN, Warszawa 2009.

Twardowski A., Kształtowanie dialogowej kompetencji komunikacyjnej u uczniów niepetnosprawnych intelektualnie, Wydawnictwo Naukowe UAM, Poznań 2002. 
White G.M., Representing Emotional Meaning: Category, Metaphor, Schema, Discourse, [w:] Handbook of Emotions, red. M. Lewis, J.M. Haviland-Jones, The Guilford Press, New York 2000.

Wishart J.G., Cebula K.R., Willis D.S., Pitcairn T.K., Understanding of facial expressions of emotion by children with intellectual disabilities of differing aetiology, Journal of Intellectual Disability Research, 2007, 51(7).

Wiśniewska-Kin M., "Miłość jest jak wiatrak“ - czyli o poznawczej naturze metafor dziecięcych, Wydawnictwo UŁ, Łódź 2009.

Wróbel M., Zarażanie afektywne. O procesie transferu emocji i nastroju między ludźmi, Wydawnictwo Naukowe PWN, Warszawa 2016.

Wyczesany J., Gajdzica Z., Uwarunkowania edukacji i rehabilitacji uczniów o specjalnych potrzebach rozwoju, Wydawnictwo Naukowe AP, Kraków 2006.

Wygotski S., Myślenie i mowa, PWN, Warszawa 1989.

Zabłocki K.J., Upośledzenie umysłowe - wybrane zagadnienia edukacji i terapii, Novum, Płock 2003. 
